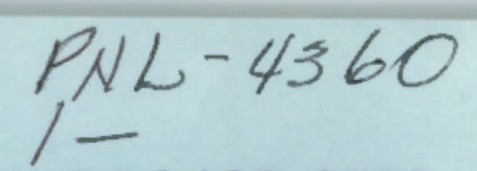

NUREG/CR-2856 PNL-4360

\title{
A Review of Fugitive Dust Control for Uranium Mill Tailings
}

Prepared by C. T. Li, M. R. Elmore, J. N. Hartley

Pacific Northwest Laboratory

Operated by

Battelle Memorial Institute

Prepared for

U.S. Nuclear Regulatory

Commission 


\section{NOTICE}

This report was prepared as an account of work sponsored by an agency of the United States Government. Neither the United States Government nor any agency thereof, or any of their employees, makes any warranty, expressed or implied, or assumes any legal liability of responsibility for any third party's use, or the results of such use, of any information, apparatus, product or process disclosed in this report, or represents that its use by such third party would not infringe privately owned rights.

\section{Availability of Reference Materials Cited in NRC Publications}

Most documents cited in NRC publications will be available from one of the following sources:

1. The NRC Public Document Room, 1717 H Street, N.W. Washington, DC 20555

2. The NRC/GPO Sales Program, U.S. Nuclear Regulatory Commission, Washington, DC 20555

3. The National Technical Information Service, Springfield, VA 22161

Although the listing that follows represents the majority of documents cited in NRC publications, it is not intended to be exhaustive.

Referenced documents available for inspection and copying for a fee from the NRC Public Document Room include NRC correspondence and irternal NRC memoranda; NRC Office of Inspection and Enforcement bulletins, circulars, information notices, inspection and investigation notices; Licensee Event Reports; vendor reports and correspondence; Commission papers; and applicant and licensee documents and correspondence.

The following documents in the NUREG series are available for purchase from the NRC/GPO Sales Program: formal NRC staff and contractor reports, NRC-sponsored conference proceedings, and NRC booklets and brochures. Also available are Regulatory Guides, NRC regulations in the Code of Federal Regulations, and Nuclear Regulatory Commission Issuances.

Documents available from the National Technical Information Service include NUREG series reports and technical reports prepared by other federal agencies and reports prepared by the Atomic Energy Commission, forerunner agency to the Nuclear Regulatory Commission.

Documents available from public and special technical libraries include all open literature items, such as books, journal and periodical articles, and transactions. Federal Register notices, federal and state legislation, and congressional reports can usually be obtained from these libraries.

Documents such as theses, dissertations, foreign reports and translations, and non-NRC conference proceedings are available for purchase from the organization sponsoring the publication cited.

Single copies of NRC draft reports are available free upon written request to the Division of Technical Information and Document Control, U.S. Nuclear Regulatory Commission, Washington, DC 20555.

Copies of industry codes and standards used in a substantive manner in the NRC regulatory process are maintained at the NRC Library, 7920 Norfolk Avenue, Bethesda, Maryland, and are available there for reference use by the public. Codes and standards are usually copyrighted and may be purchased from the originating organization or, if they are American National Standards, from the American National Standards Institute, 1430 Broadway, New York, NY 10018.

GPO Printed copy price: $\$ \$ 5.00$ 
NUREG/CR-2856

PNL-4360

RU

\section{A Review of Fugitive Dust Control for Uranium Mill Tailings}

Manuscript Completed: June 1982

Date Published: January 1983

Prepared Ly

C. T. Li, M. R. Elmore, J. N. Hartley

Pacific Northwest Laboratory

Richland, WA 99352

\section{Prepared for}

Division of Health, Siting and Waste Management

Office of Nuclear Regulatory Research

U.S. Nuclear Regulatory Commission

Washington, D.C. 20555

NRC FIN B2370 


\section{ABSTRACT}

An immediate concern associated with the disposal of uranium mill tailings is that wind erosion of the tailings from an impoundment area will subsequently deposit tajlings on surrounding areas. Pacific Northwest Laboratory (PNL), under contract to the U.S. Nuclear Regulatory Commission, is investigating the current technology for fugitive dust control.

Different methods of fugitive dust control, including chemical, physical, and vegetative, have been used or tested on mill tailings piles. This report presents the results of a literature review and discussions with manufacturers and users of available stabilization materials and techniques. 
SUMMARY

One of the concerns associated with the disposal of uraniurn mill tailings is that wind erosion may carry them out of the impoundment area. Recent Nuc lear Regulatory Commission (NRC) regulations require that fugitive dusting be controlled to prevent the tailings from spreading onto nearby areas.

The Pacific Northwest Laboratory (PNL) is investigating the technology for controlling fugitive dusting. This report presents the first phase of the study-a review of the literature and discussions with stabilizer manufacturers and end users including mining companies, the highway construction industry, the Soil Conservation Service of the Department of Agriculture, etc.

Much research has been done by mining companies, the U.S. Bureau of Mines (BM) and for the Environmental Protection Agency (EPA) on stabilization of waste tailings for the prevention of fugitive dusting. Chemical, physical, and vegetative methods of dust control have been used or tested on inactive tailings piles.

Chemical stabilizers react with the tailings to form a wind-resistant crust or surface layer. Of chemicals whose test results have been recorded, the resinous, elastomeric polymer, ligninsulfonate, bituminous base, wax, tar and pitch products have proved effective long-term stabilizers for fine-sized mineral wastes.

Many materials have been used to physically stabilize fine tailings. Rock and soil obtained from areas adjacent to the tailings to be covered is most often used. Soil provides an effective cover and a habitat for encroachment of local vegetation. However, it is not always available in areas contiguous to the tailings piles and, even where available, it may be too costly to apply. Other physical methods of control which have been employed are covering the tailings with bark or harrowing straw into the top few inches of tailings. windscreens or windbreaks have also been used successfully at some tailings sites.

Successful vegetative stabilization produces a self-perpetuating ground cover that entraps and allows gemination of native plant seeds that will grow without the need for irrigation or special care. However, the use of vegetative dust control techniques are not considered to be cost effective at most uranium mills particulary during the active life of the mill, since the tailings beach area (the major source of dust) is changing or being built up with time. Also, process chemicals in the tajiings of ten inhibit the growth of veget ation. 



\section{CONTE NTS}

SUMMARY

INTROOUCTION

CONCLUSIONS

RE COME NDATIONS

OVERVIEW OF FUGITIVE DUST GENERATION FROM

URANIUM MILL TAILINGS

URANIUM MILLING

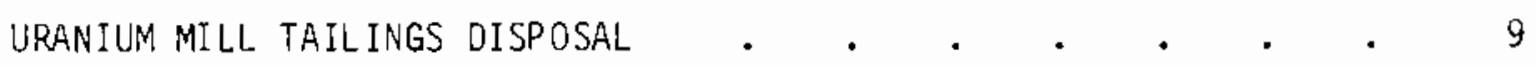

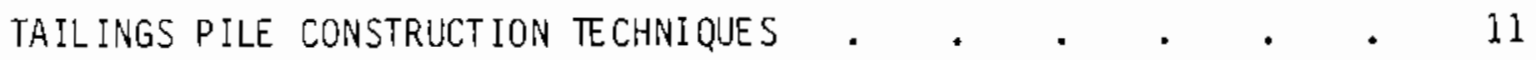

FUGITIVE DUST EMISSIONS

MECHANISMS OF TAILINGS SAND MOVEMENT ANO STRATEGY

FOR CONTROLLING FUGITIVE DUST . . . . . . . . . . . . . . . 17

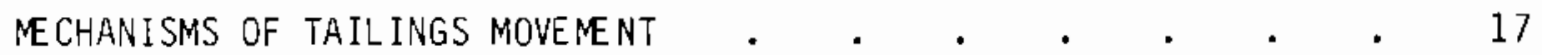

Airborne Suspension . . . . . . . . . . . . . . 17

Saltation . . . . . . . . . . . . . . 17

Surface Creep . $\quad . \quad$. $\quad . \quad$. $\quad . \quad$. $\quad . \quad . \quad 18$

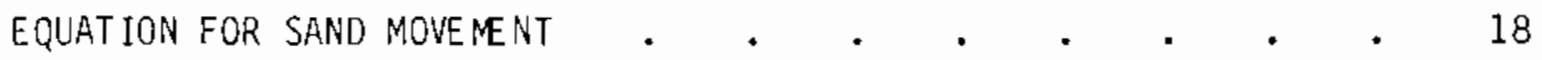

STRATEGY FOR FUGITIVE DUST CONTROL

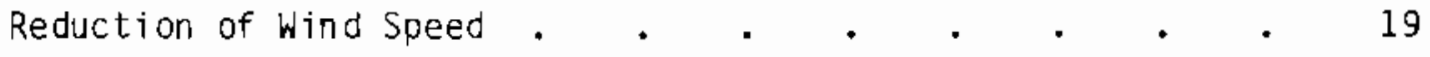

Entrapment of Falling Sand . . . . . . . . 19

Control of Particle Size Distribution . . . . . 20

Change in Surface Characteristics . . . . . . 20

Increase in Density or Size of particles . . . . 20

Increase in Moisture Content . . . . . . . . 21

Decrease of the Surface Roughness . . . . . . . 21 


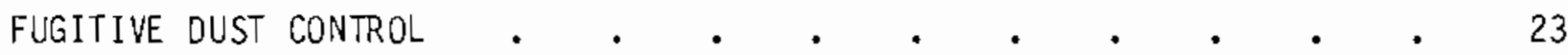

CONTROL METHODS $. \quad . \quad . \quad . \quad . \quad . \quad . \quad . \quad . \quad . \quad . \quad . \quad 23$

Physical Methods . . . . . . . . . 23

Cnemical Methods . . . . . . . . . . . 24

Biologicar Methods . . . . . . . . . . 25

INDUSTRIAL USES OF DUST SUPPRESSION TECHNOLOGY $\quad$ • $\quad$ • $\quad 25$

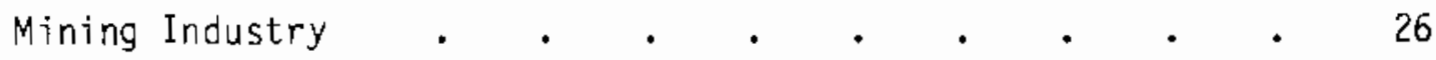

Department of Agriculture--Soil Conservation Service . . 30

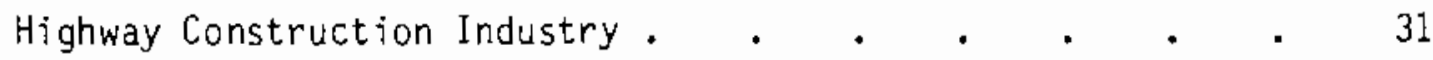

Electric Utilities . . . . . . . . . . . 31

The Military . . . . . . . . . . . 32

REVIEW OF SELECTED EXPERIMENTAL PROGRAMS RELATED TO

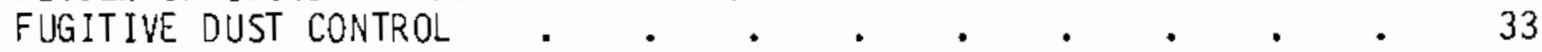

Soil Stabilization for Agricultural Purposes . . . . . 33

Coal Industry . . . . . . . . . . . . 37

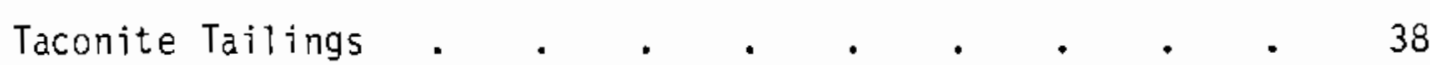

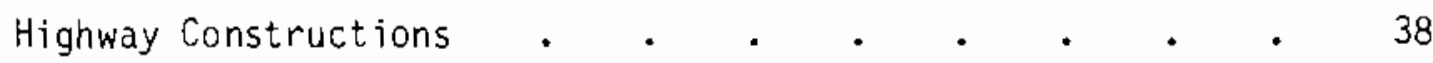

CRITERIA FOR SELECTION OF DUST CONTROL METHOD . . . . . . . 39

Effectiveness . . . . . . . . . . . . . 39

Durability . . . . . . . . . . . . 40

Practicability. . . . . . . . . . . . . 40

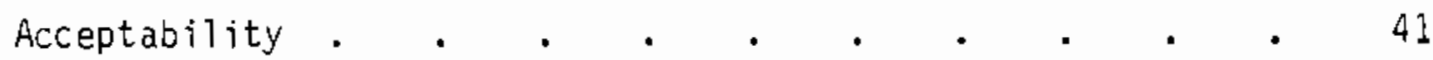

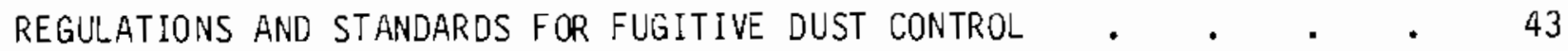

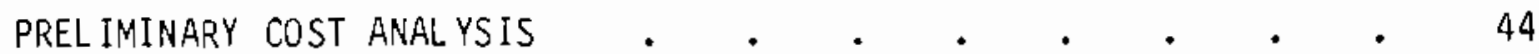

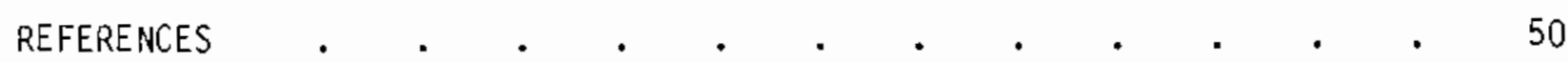

APPENDIX A - ADDITIONAL MANUFACTURERS CONTACTED ..$\quad \cdot \quad \cdot \quad \cdot \quad$ A.I 


\section{F IGURES}

1 Simplified Flow Diagram of Uranium Milling . . . . . . 8

2 Typical Tailings Pile Construction . . . . . . . . . . . 9

3 Common Tailings Disposal Methods . . . . . . . . . . . . 12

4 Comparison of Cost and Effective Life for Selected Dust Suppressants . . . . . . . . . . . . 48

\section{TABLES}

1 Typical Sieve Analyses for Uranium Mill Tailings(a) . • . 10

2 Profile of U.S. Uranium Mills Operating in 1979 (NRC 1980) • . 14

3 Potential Chemical Stabilizers for Use on Uranium Mill Tailings . 34

4 Comparison of Costs For Selected Stabilization Techniques . • 49 



\section{INTRODUCTION}

Many uranium mill tailings piles are subject to serious wind erosion. Before these tailings $c$ an be permanently disposed of and while the mill is operating, interim stabilization of the tailings pile is important to minimize the spread of contamination to nearby areas.

Windblown particles from uranium mill tailings have been found at distances of 0.8 to $3.2 \mathrm{~km}$ from the site and contain radionuclides (uranium and daughter products), toxic elements in the original ore, and small amounts of residual chemicals used in the milling process (Schwendiman 1980). These airborne particles pose a potential hazard to the environment since they are the 1 argest potential source of offsite radiation exposure excluding radun. For example, the annual release of airborne particles under 100 um in diameter from a hypothetical 50 ha tailings pile is estimated at about $370 \mathrm{~g} / \mathrm{m}^{2} \cdot \mathrm{yr}$ or $185 \mathrm{MT} / \mathrm{yr}$ (US NRC 1980). These airborne particles should be reduced to a level "as low as is reasonably achievable." The use of chemical, physical and biological stabilizers could achieve this.

Under contract to the U.S. Nuclear Regulatory Comrission's (NRC's) office of Nuclear Regulatory Research, the Pac if ic Northwest Laboratory (PNL) is investigating the effectiveness, practicability, durability, and cost of interim stabilization techniques and strategies for reducing particulate dusting from exposed tailings surfaces. Results of this study will provide the technical information necessary to allow NRC staff to evaluate plans for interim stabilization of uranium mill tailings over a wide range of site and environmental conditions. They also support enforcement of 40 CFR 190 and will implement requirements of proposed Appendix A, Criteria 8 of 10 CFR 40 .

The first phase of this study was to carry out a literature search to ident ify the more promising tailings stabilization materials and techniques. The information presented in this report provides the basis for conducting both laboratory and field studies to determine the effectiveness of various physical and chemical soil stabilizers in preventing wind erosion from uranium mill tailings. In addition to the literature review selected mining companies including uranium, copper, molybdenum producers and others, as well as the U.S. Forest Service and highway departments, were contacted about their use of dust suppressants. Manufacturers of dust suppressants were also contacted and samples of their products were obtained. Selected uranium tailings piles were visited to assess the problems associated with the use of stabilizers. 

CONCLUSIONS

The specif ic conelusions from this study are:

- Chemical, physical, and biological methods to control fugitive dust from tailings are available and have been used in the mineral industries.

- Selection of the control method to be used depends upon site-specif ic cond itions.

- In general, chemical stabilization has been shown to be the most cost effective technique for shorter-term wind erosion control for tailings pile. The effectiveness of chemical stabilizers depends on application rate, dilution, method of application and physical and chemical characteristics of the tailings surface.

- Physical stabilization methods including straw or bark covers, watering, windscreens, and fences, could be effective in controlling fugitive dust, but are not expected to be cost-effective for interim stabilization where there is continuous deposition of new tailings. However, in areas that are awaiting final stabilization these techniques could be considered. Soil covers could be effective as an interim stabilization technique if the soil material was nearby: $A$ cost analysis would be needed to determine if. this technique would be suitable.

- The cost of interim stabilization depends on many factors including site preparation, application rate, application procedure, and site monitoring and maintenance. The cost to chemically stabilize a hypothetical 100 acre tailings site is expected to range from about $\$ 20,000 / y r$ to over $\$ 100,000 / y r$, depending on the chemical stabilizer used, its application rate and life expectancy. A cost analys is would be needed to help select an appropriate chemical stabilizer.

- Vegetative stabilization is not cost effective because of the lack of top soil and the changing nature of an active tailings pile. 



\section{RECOMME NDATIONS}

The following recommendations are made as a result of this review.

- Laboratory studies should be conducted to determine the most effective chemicals to stabilize uranium mill tailings. These studies should include characterization of the tailings and evaluation of dust control methods using wind tunnel tests. A range of tests including wet-dry cycling, UV exposure, and freeze-thaw cycling should be conducted to evaluate the expected life of the chemical stabilizers.

- Field studies should be conducted at an active mill site using the most pronising stabilizers ident ified in the laboratory tests. Selected chemical stabilizers should be applied at several appli$c$ ation rates and the test plots monitored to determine the effectiveness of the stabilization procedure. From the resulting data engineering spec if ications can be prepared.

- Based on the data obtained from the field tests an economic anaiysis of fugitive dust control for a typical uranium mill tailings pile should be made. 



\section{OVERVIEW OF FUGITIVE DUST GENERATION FROM}

URANIUM MILL TAILINGS

This section provides a discussion of the fugitive dust emissions from tailings produced in the uranium industry. These emissions are associated with the major tailings disposal operations which requires storage of large quantities of waste materials.

The following subsections ident ify the source and characteristics of the fugitive dust emissions including: 1) the specific process operations that produce the tailings 2) tailings disposal and 3) characteristics of the fugitive dust emissions.

\section{URANI UM MILLING}

The purpose of the milling process is to concentrate the uranium from the few tenths of a percent found in the ore to a purity of about $90 \% \mathrm{U}_{3} \mathrm{O}_{8}$ in a product called yellow cake. The exact milling process depends on the characteristics of the ore including the presence of other minerals such as vanadium, copper, and molybdenum, which may be significant byproducts or process cont aminants.

A simplified flow diagram of uranium milling is shown in Figure 1. Since uranium is usually finely disseminated in the ore, the ore must be crushed and ground to a particle size fine enough to liberate the uranium during leaching, usually fine beach sand $(<400 \mu \mathrm{m})$. Dry crushing of the rock is usually done in jaw crushers, gyratory crushers, etc. Water is added in the grinding process using rod mills, ball mills, autogenous or semi-autogenous mills.

The next step is to leach the ground ore unt 11 greater than $93 \%$ of the uranium is dissolved in the leaching solution. Two types of leaching processes extract uranium from ore: acid leach and carbonate leach. Acid leach is used most often, but if the ore is high in lime, a carbonate leach prevents excessive acid consumption. One disadvantage to employing the carbonate leach is that of ten the ore needs to be ground to a smaller particle size, which increases energy consumption and could lead to greater dust control problems on the tailings pile.

After the uranium is dissolved from the ore, the leach solution containing the solubilized uranium and the waste solids (tailings) is separated using a series of countercurrent decantation thickeners, classifiers, etc. The tailings are then discharged from the final thickener to the impoundment area as a slurry containing about $50 \%$ to $60 \%$ solids. It is the impoundment area or tailings disposal site that creates the major source of fugitive dust emmissions.

Once the leach solution, now called pregnant liquor, is clarified, the uranium is selectively extracted from the liquor by either an ion exchange process or a liquid solvent extraction process. The uranium is eluted from the ion exchange media or extracted from solvent extraction organic and the 


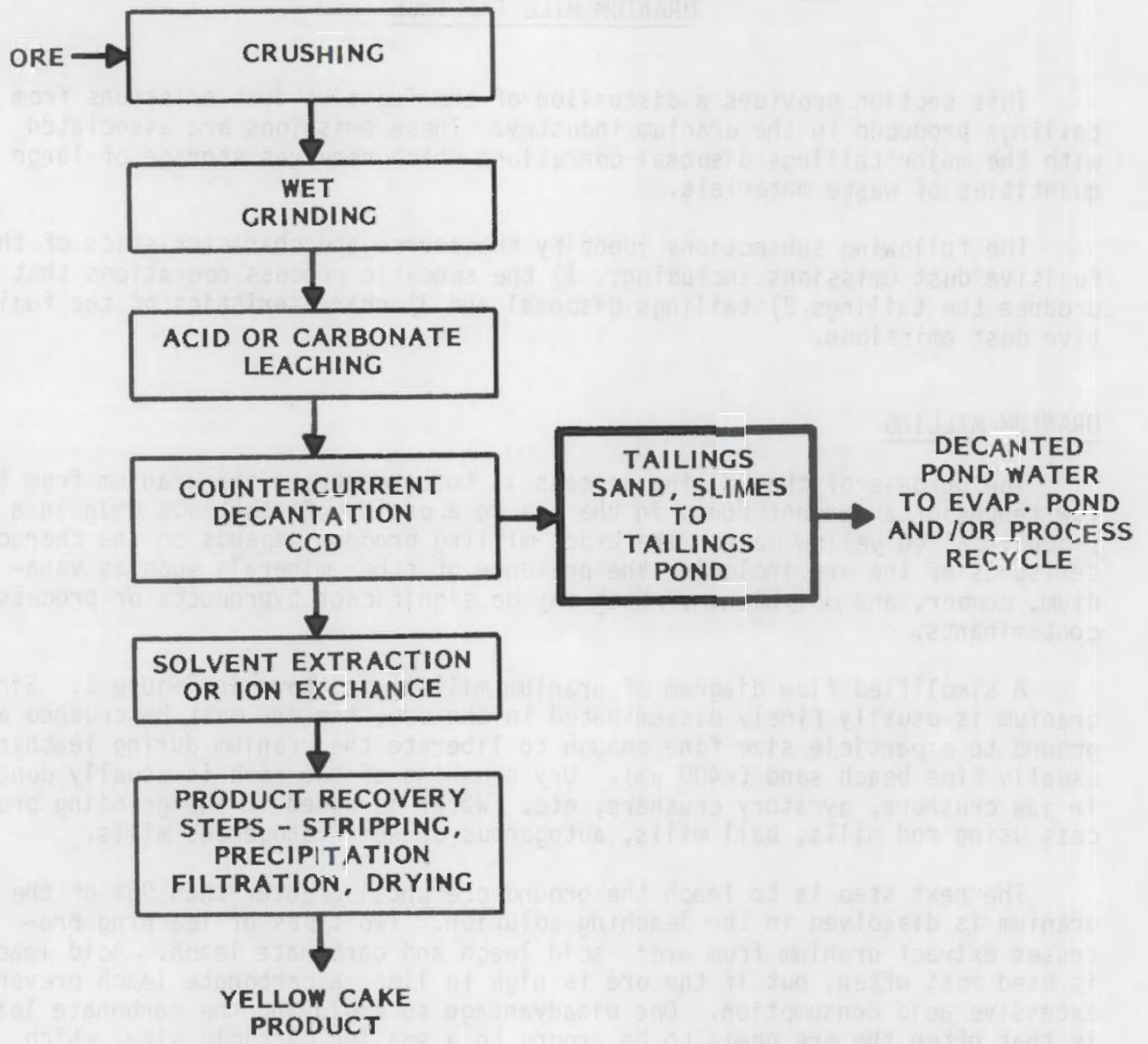

FIGURE 1. Simplified Flow Diagram of Uranium Milling 
resultant extract is adjusted to precipitate uranium out of solution as yellow cake. Finally the yellow cake is filtered, dried, and packaged in drums for shipment to an enrichment facility.

Much smaller amounts of uranium are produced by unconventional processes. These include in-situ leaching recovery from mine water, dump leaching, copper mine liquor leaching, and wet process phosphoric acid plants. Since these processes do not directly produce tailings that are subject to wind erosion, they will not be considered in this report.

\section{URANIUM MILL TAILINGS DISPOSAL}

Tailings are the solid waste products of milling and consist of two basic fractions--sands and slimes--which contain potentially hazardous radioactive and chemical materials. The weight of the sand fraction of the tailings is generally two or three times the weight of the slimes. However, the amount of radioactive materials in the tailings, in particular the $226 \mathrm{Ra}$, is not partitioned among the solids in the same ratios. It has been estimated that as; much as $85 \%$ of the insoluble radioactive materials originally in the feed ore is contained in the slime fraction (<200 mesh)(NRC 1980).

Whether the uranium tailings are acidic or basic, they are transported to the disposal site as a slurry. At most uranium mills the method of disposal is impoundment of the tailings behind a specially prepared dam. It is this disposal method that ultimately leads to windblown (fugitive) dust. In general the tailings are discharged through lateral branch lines (Figure 2) and deposited on a beach upstream of the dam. The size distribution of the tailings and

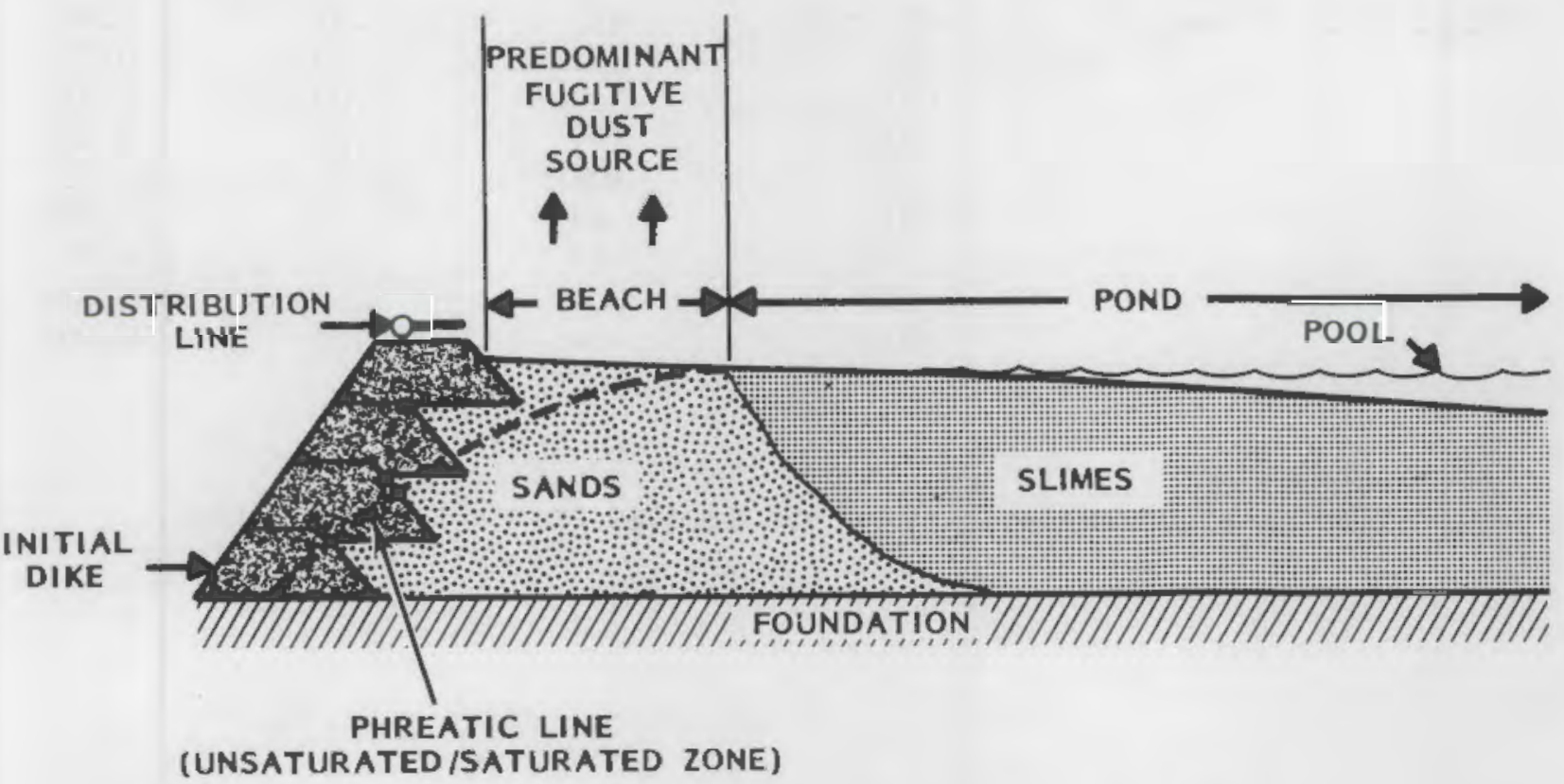

FIGURE 2. Typical Tailings Pile Construction 
the solids density at deposition allow some segregation of sand and slimes. A typical size distribution of acid tailings is shown in Table 1.

Tailings disposal behind a dam creates at least three areas of concern: 1) the dam's structural stability, 2) pollution under normal operating conditions from contaminated effluent escaping from the containment area into streams or ground water, and 3) loss of tailings by water and wind erosion. Windblown particles from a uranium tailings pile could contain radium and its daughter products, toxic elements in the original ore such as heavy metals, and residual amounts of process chemicals. Because of these risks, extra attention needs to be given to the safe design, construction, and operation of the tailings disposal site.

TABLE 1. Typical Sieve Analyses for Uranium Mill Tailings(a)

\begin{tabular}{|c|c|c|c|c|}
\hline 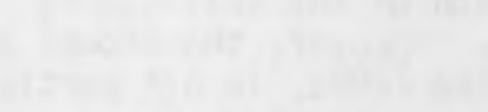 & $\begin{array}{c}\text { Screen } \\
\text { Size, mesh } \\
\end{array}$ & $\begin{array}{l}\text { Opening } \\
\text { Size, } \mu \mathrm{m}\end{array}$ & Wt & $\begin{array}{c}\text { Cumulative } \\
\text { Wt }\end{array}$ \\
\hline Acid Leach Beach Sands & $\begin{array}{l}-16+20 \\
+30 \\
+40 \\
+50 \\
+70 \\
+100 \\
+140 \\
+200 \\
+270 \\
+400 \\
-400\end{array}$ & $\begin{array}{r}840 \\
590 \\
420 \\
297 \\
210 \\
149 \\
105 \\
74 \\
53 \\
38 \\
--\end{array}$ & $\begin{array}{r}0.38 \\
0.35 \\
1.00 \\
8.93 \\
22.57 \\
31.97 \\
17.90 \\
9.00 \\
2.54 \\
2.77 \\
2.59\end{array}$ & $\begin{array}{r}0.38 \\
0.73 \\
1.73 \\
10.66 \\
33.23 \\
65.20 \\
83.10 \\
92.10 \\
94.64 \\
97.41 \\
100.00\end{array}$ \\
\hline Acid Leach Slimes & $\begin{array}{l}-30+40 \\
+50 \\
+70 \\
+100 \\
+140 \\
+200 \\
+270 \\
+400 \\
-400 .\end{array}$ & $\begin{array}{r}420 \\
297 \\
210 \\
149 \\
105 \\
74 \\
53 \\
38 \\
-\end{array}$ & $\begin{array}{r}0.07 \\
0.63 \\
2.08 \\
6.62 \\
10.07 \\
13.79 \\
6.67 \\
8.53 \\
51.54\end{array}$ & $\begin{array}{r}0.07 \\
0.70 \\
2.78 \\
9.40 \\
19.40 \\
33.26 \\
39.93 \\
48.46 \\
100.00\end{array}$ \\
\hline
\end{tabular}

(a) Based on sieve analysis by PNL of samples from 4 tailings piles. 


\section{TAILINGS PILE CONSTRUCTION TECHNIQUES}

The majority of conventional uranium mills use a technique for tailings dam construction known as the upstream method. This method is also the principal tailings dam construction technique for all other mining industries, and has been since early mining days.

For upstream construction a starter dike, or toe dam, is built using local soils. Tailings slurry is then deposited behind the dam by spigoting at regular intervals from the main distribution line, which usually runs around the entire periphery of the dam. In some instances cyclones are placed at the spigot points to enhance separation of the sands and slimes. As the slurry is discharged from the pipe the sands deposit in a wide beach area against the dam, and the slimes are carried away from the dike toward the center of the pond. A clear pond forms roughly in the center of the pile as the slimes settle out, and the water in the pond is removed through a decant tower. The decanted water is generally recinculated to the mill for further use.

As the depth of deposited tailings increases at the dam, the dike must continually be raised in advance. The dikes above the toe dam are most often constructed of tailings dredged up from the beach area. By using tailings the costs of construction are lower than if other material was hauled in. A disadvantage in using tailings for dam construction is that they can be less stable, raising the potential for dam failure. One limitation to this technique is operating in a manner that maintains safe pore water pressures in the tailings. The upstream method usually requires a wide beach area behind the dam to keep the phreatic line low enough. (The phreatic line is the zone between water saturated and unsaturated tailings, as shown in Figure 3.) However, in maintaining the wide beach area for stability, a large portion of the tailings are left uncovered. As these sands dry out they are, in many cases, highly susceptible to wind erosion.

Other methods of construction exist that can minimize the beach sands areas not covered by water. One of these is referred to as downstream construction. As with the upstream method, downstream construction starts with a toe dam of native soils. Subsequent lifts are built downstream from the toe dam using native soils, mine wastes or cycloned tailings (see Figure 3 ). With this method the whole body of the dam can be compacted. Impervious cores and/ or drainage zones $c$ an also be incorporated into the dam to aid in drainage control. The result is a dam that can store ponded water closer to the face of the dam with less potential for failure. Construction costs are usually much higher for this method and the amount of material needed for the downstream construction is far more than for the upstream method.

A compromise of the two methods is known as centerline construction. In this method tailings are deposited through peripheral spigots, creating a nominal sand beach (see Figure 3 ). The dam is actually built straight up from the toe dam and requires less material than downstream construction. Drainage systems can be built into the dam. Construction costs lie between those of the upstream and downstream construction. Through proper design, the centeriine dam can be very resistant to failure. 


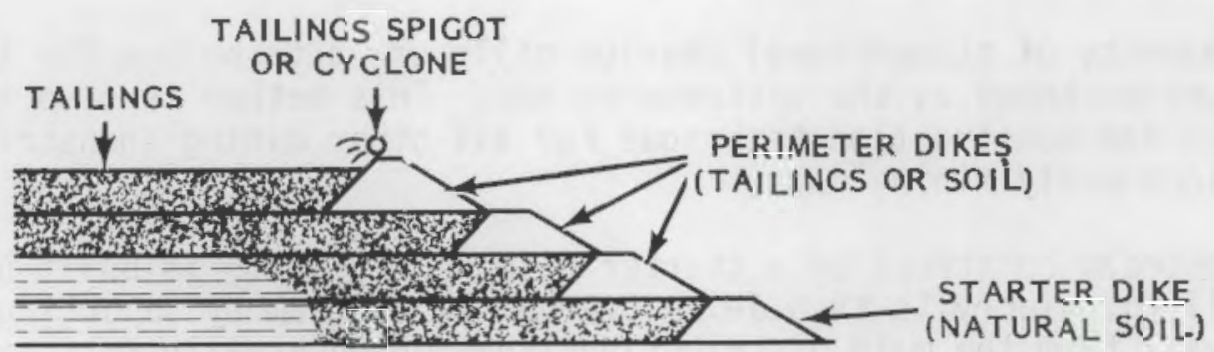

UPSTREAM CONSTRUCTION

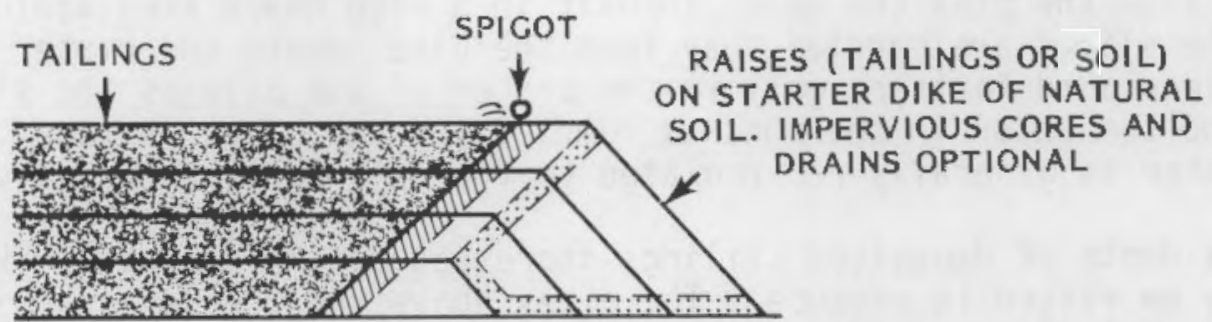

DOWNSTREAM CONSTRUCTION

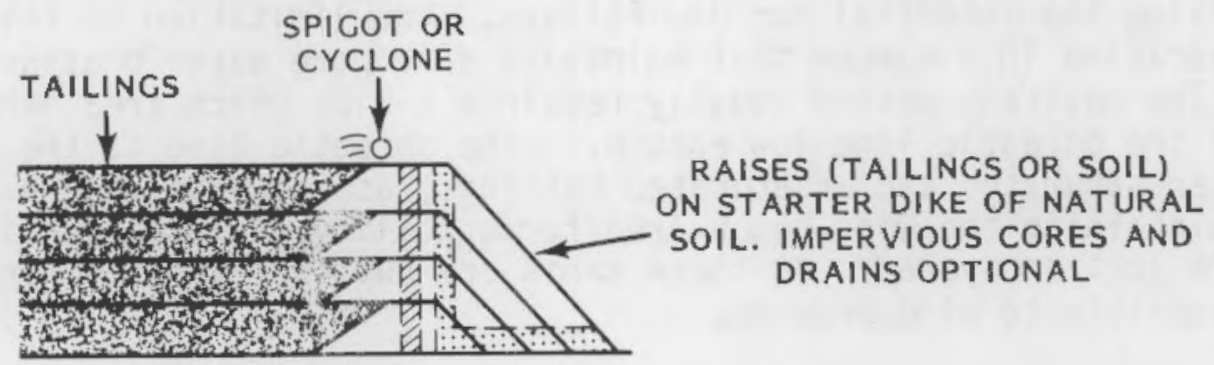

CENTERLINE CONSTRUCTION

FIGURE 3. Common Tailings Disposal Methods 
The major source of fugitive dust on a uranium tailings pile is from the dried out beach areas or inactive areas of the pile (Figure 2). The continual building of the tailings pile results in a highly variable and changing surface condition. In some cases the residual chemicals in the process water will cause a surface layer to fom which will reduce fugitive dusting if it remains undisturbed. However, the heterogeneity in surface texture, moisture content, particle size distribution and spatial variations in meteorology results in a variable pattern of fugitive dust emission from one location to a nother.

Because of these variables it is very hard to predict the fugitive dust mass flux of particles leaving the tailings surface. An attempt was made in NRC's final generic environmental impact statement on uranium milling to model the windblown dust loss from a tailings pile. The dust loss from the tailings surface of a 50 ha tailings pile for particles less than $100 \mu \mathrm{m}$ dia was calculated to be $370 \mathrm{~g} / \mathrm{m}^{2} \cdot \mathrm{yr}$ or $185 \mathrm{mT} / \mathrm{yr}$ (NRC 1980).

Resuspended tailings material have been found as far as $8 \mathrm{~km}$ from an active mill (Schwendiman 1980). Schwendiman also found that the concentration of radionuclides on the airborne particles was greater in the smaller size particles (<125 um dia). The mass flux of particles was measured with samplers at various distances downwind from the tailings pile. Fluxes were highly variable depending on the location of the sampler, windspeed, and moisture. Based on the results of this study it was concluded that there are considerable uncertainties in applying simplistic models to complex phenomena such as suspension, deposition and transport of windblown dust. Therefore, the fugitive dust source term for any tailings pile is difficult to estimate.

Most tailings piles do experience some form of fugitive dust emission during and after mill operation. The magnitude of the fugitive dust source for uranium tailings can be seen in Table 2 which presents a profile of operating U.S. uranium mills. There are nearly 3500 acres of active tailings piles that can produce fugitive dust (NRC 1980). It is this dust emission that needs to be reduced to an acceptable level. 
TABLE 2. Profile of U.S. Uranjum Mills Operating in 1979 (NRC 1980)

\begin{tabular}{|c|c|c|c|c|c|}
\hline Location & Company & $\begin{array}{l}\text { Maximum } \\
\text { Capacity, } \\
\text { MT per day } \\
\end{array}$ & $\begin{array}{r}\text { Leaching } \\
\text { Process }\end{array}$ & $\begin{array}{c}\text { Tailings } \\
\text { Pond Area, } \\
\text { acres }\end{array}$ & $\begin{array}{l}\text { Amount o } \\
\text { ajlings } \\
10^{6} \mathrm{MT}\end{array}$ \\
\hline \multicolumn{6}{|l|}{ COLORADO } \\
\hline Canon City & Cotter & 1300 & $\begin{array}{l}\text { Ac id } \\
\text { (2-stage) }\end{array}$ & 200 & 1.0 \\
\hline Uravan & Union Carbide & 1200 & $\begin{array}{l}\text { Acid } \\
(2-\text { stage })\end{array}$ & 79 & 8.8 \\
\hline \multicolumn{6}{|l|}{ NEW MEXICO } \\
\hline Cebolleta & $\begin{array}{l}\text { Sohio/Reserve } \\
\text { 0il a Minerals }\end{array}$ & 1500 & Acid & 60 & 1.4 \\
\hline Church Rock & United Nuclear & 3600 & Acid & 197 & 2.2 \\
\hline Grants & Anaconda & 6200 & Acid & 270 & 32 \\
\hline Grants & Kerr-McGee & 6300 & $A C i d$ & 250 & 24.6 \\
\hline Grants & $\begin{array}{l}\text { United Nuclear/ } \\
\text { Homestake Partners }\end{array}$ & 3100 & $\begin{array}{l}\text { Alkal ine } \\
\text { (2-stage) }\end{array}$ & 150 & 16.8 \\
\hline \multicolumn{6}{|l|}{ IEXAS } \\
\hline Falls City & $\begin{array}{l}\text { Continental } 0 i 1 / \\
\text { Pioneer Nuclear }\end{array}$ & 2900 & Acid & \multicolumn{2}{|c|}{ tailings area) } \\
\hline Panna Maria & Chevron Resources & 2200 & Acid & $\begin{array}{l}250 \text { (Total } \\
\text { tailings area }\end{array}$ & 1.2 \\
\hline \multicolumn{6}{|l|}{ UTAH } \\
\hline Blanding & $\begin{array}{l}\text { Energy Fuels } \\
\text { Nuclear }\end{array}$ & 1800 & Acid & 333 & 0 \\
\hline
\end{tabular}


TA\&LE 2. (contd)

\begin{tabular}{|c|c|c|c|c|c|}
\hline Location & Company & $\begin{array}{l}\text { Maximum } \\
\text { Capacity, } \\
\text { MT per day }\end{array}$ & $\begin{array}{l}\text { Leaching } \\
\text { Process } \\
\end{array}$ & $\begin{array}{c}\text { Tailings } \\
\text { Pond Area, } \\
\text { acres }\end{array}$ & $\begin{array}{c}\text { Amount of } \\
\text { Tailings, } \\
10^{6} \text { MT } \\
\end{array}$ \\
\hline La Sal & Rio Algom & 640 & $\begin{array}{l}\text { Alkaline } \\
\text { (2-stage) }\end{array}$ & 35 & 1.6 \\
\hline Moab & Atlas & 1100 & $\begin{array}{l}\text { Acid } t \\
\text { alkaline }\end{array}$ & 115 & 7.8 \\
\hline \multicolumn{6}{|l|}{ WASHINGTON } \\
\hline Ford & Dawn Mining & 400 & $\begin{array}{l}\text { Acid } \\
\text { (2-stage) }\end{array}$ & 106 & 2.8 \\
\hline Wellpinit & Western Nuclear & 1800 & Acid & 42 & 1.3 \\
\hline WYOMING & & & & & \\
\hline Gas Hills & Federal-American & 900 & Acid & 105 & 4.2 \\
\hline Gas Hills & Pathfinder & 2500 & $\begin{array}{l}\text { Acid } \\
\text { (2-stage) }\end{array}$ & $70-80$ & 5.8 \\
\hline Jeffrey City & Western Nuclear & 1500 & Acid & $\begin{array}{l}85 \text { (Total } \\
\text { tailings area) }\end{array}$ & 11.0 \\
\hline Natrona & Union Carbide & 1200 & Acid & $\begin{array}{l}148 \text { (Above- } \\
\text { ground) }\end{array}$ & 7.6 \\
\hline Powder River & Exxon & 2700 & Acid & 200 & 5.7 \\
\hline Powder River & Rocky Mt. Energy & 1800 & Acid & $\begin{array}{l}150 \text { (Total } \\
\text { tailings area) }\end{array}$ & 8.0 \\
\hline Shirley Bas in & Pathf inder & 1600 & Acid & 150 & \\
\hline Shirley Basin & Petrotamics & 1500 & Acid & 160 & 2.8 \\
\hline
\end{tabular}



MECHANISMS OF TAILINGS SAND MOVEMENT AND STRATEGY

FOR CONTROLLING FUGITIVE DUST

When a wind blows across a dry surface such as the beach area of a tailings pile, it picks up grains of tailings sand and carries them onward for a distance until the wind ceases. Blowing winds create problems of fugitive dust, which for health and other reasons must be controlled.

The bulk movement of tailings sand usually depends on the wind velocity, surface contour of the tailings pile, and physical properties of tailings sand such as shape, size distribution, and density of particies, etc. Understanding the mechanisms of sand movement by wind on the tailings surface will help us to develop an effective dust control strategy to mitigate the sand blowing problems.

In this section mechanisms of sand movement by winds will be discussed and then based on this discussion, a fugitive dust control strategy will be proposed. The strategy developed in this section is theoretical; it will be used as a guideline to develop more practical dust control methods in a later section.

\section{MECHANISMS OF TAIL INGS MOVEMENT}

According to the classic work done by R. A. Bagnold (1954) the mechanisms of sand movement are airborne suspension, saltation and surface creep.

Airborne Suspension

Particles with diameters less than $100 \mu \mathrm{m}$ can be suspended to form a cloud of dust when they are dislodged from the ground surface or tailings by wind or mechanical disturbances such as traffic. Particles of this size usualiy have downward teminal velocities smaller than the upward velocity of eddies in a turbulent wind. Therefore, they can be suspended in the air and carried through the atmosphere for long periods and to great distances from their original locations under high wind conditions. A particle in suspension traveis at a velocity equal to the average forward speed of the wind. As long as the particle rides on the eddies of the turbulent wind, it will be suspended. However, once the particle falls out of the eddies, it loses its upward momentum and eventualiy falls back to the ground.

\section{Saltation}

Saltation occurs with particles of diameters between 100 and $500 \mu \mathrm{m}$. When a fast moving particle impacts the surface, it may bounce high into the air with almost perfect resilience, or it may dislodge and eject particles into the air as a result of momentum transfer. While the particle rises into the air, it acquires additional momentum from the wind and is carried downwind. Due to gravity the particle follows a downward curved path. The angle between the 
trajectory of the falling particle and the surface of the ground is about 10 to $16^{\circ}$, depending upon the density of the falling particle, size of the particle, how high it rose, and the speed of the wind. The striking and bouncing actions of a particle continue as long as energy received from the wind by the saltating particle is larger than or equal to that lost. The momentum of a saltating particle can be consumed by impacting and ejecting other particles of about the same size on the ground or in pushing (or roiling) of a particle too heavy to be ejected into the air. The energy of a saltating particle can also be consumed when the particle hits the surface of an object with non-ideal (or low) elastic modulus such as straw, bark, etc. In this case the elastic object on the ground absorbs most of the energy carried by the falling particle.

\section{Surface Creep}

Particles with diameters greater than about $500 \mu \mathrm{m}$ are too heavy to be airborne or saltated, but they move on the surface of the ground by surface creep. These particles are rolled on the surface by strong winds and by exchange of momentum after impact with smalier, saltating particles. Such a high-speed particle may possess a high momentum energy, and by its impact it can move a surface particle six times its diameter, or more than 200 times its own weight. Although a large portion of the momentum received by particles on the ground is ultimately lost in friction, the net result of the continued bombardment of the surface by particles in saltation is a slow forward creep of the particles staying on the ground. Particles in saltation receive energy of winds directly, while particles moved by surface creep acquire wind energy indirectly from the impact of saitating particles.

\section{EQUATION FOR SAND MOVEMENT}

By performing experiments in wind tunnels Bagnold was able to simulate and study the movement of sand. He ident ified the three mechanisms of sand movement by using various sizes of particles under different wind velocities. From his experiments he concluded that both airborne suspension and surface creep do not resist or slow down the wind. In other words, these two mechanisms consume only a very small amount of wind energy. However, sand particles moved by the saltation can dissipate a significant amount of the energy because they directly acquire energy from the wind when they rise into the air and are carried by the wind. He also observed that about three quarters of total sand movement was by saltation and about one quarter was by surface creep. Airborne suspension took place only when a large amount of fine particles (less than $100 \mu \mathrm{m}$ ) were present.

Based on works by Bagnold, Belly and Gillette, the horizontal flux of various soil types can be estimated by the following equation: 


$$
\begin{aligned}
q & =C U \star^{2}\left(U^{\star}-U_{t}^{\star}\right) \\
& =C\left[\frac{U_{Z}}{2.5 \ln \left(Z / Z_{0}\right)}\right]^{2}\left[\frac{U_{Z}}{2.5 \ln \left(Z / Z_{0}\right)}-A \sqrt{\frac{g d(0-\rho)}{\rho}}(1.8+0.261 n w)\right]
\end{aligned}
$$

where: $U^{*}=$ friction velocity, $\mathrm{cm} / \mathrm{sec}$

$$
\begin{aligned}
U^{*} t & =\text { threshold friction velocity, } \mathrm{cm} / \mathrm{sec} \\
q & =\text { horizontal particle movement by the saltation process, } \mathrm{g} / \mathrm{cm} / \mathrm{sec} \\
Z & =\text { height above surface, cm } \\
U_{Z} & =\text { wind velocity at height } z, \mathrm{~cm} / \mathrm{sec} \\
Z_{0} & =\text { surface roughness height, at which } U_{Z}=0 \\
\sigma & =\text { density of the graim, } \mathrm{g} / \mathrm{cm}^{3} \\
\rho & =\text { density of air, } \mathrm{g} / \mathrm{cm}^{3} \\
g & =\text { gravitational constant, } \mathrm{cm} / \mathrm{sec}^{2} \\
d & =\text { average diameter of the grain, } \mathrm{cm} \\
W & =\text { water content, } \% \\
C & =\text { constant depends on the soil and surface condition, } \mathrm{g}-\mathrm{sec}^{2} / \mathrm{cm}^{4} \\
A & =\text { dimensionless coefficient }
\end{aligned}
$$

From this equation it $c$ an be seen that the amount of sand moved by saltation is proportional to the wind velocity raised to 2 nd and 3 rd powers. Also, as sand density, particle diameter, and moisture content increase, the amount of sand moved by the saltation decreases. Understanding these mechanisms of sand movement and the equation for calculating the amount of sand movement by the wind will help in developing a useful strategy for dust control.

\section{STRATEGY FOR FUGITIVE DUST CONTROL}

Since the saltation of sand accounts for about three quarters of the total sand movement by the wind, develop effective methods must be developed to control the saltation mechanism. The following strategies are developed based on the study of these mechanisms and equation of sand movement discussed in the above.

\section{Reduction of Wind Speed}

The speed of the wind plays a very important role in sand movement, which is proportional to the speed of the wind raised to 2 nd and 3 rd powers. In other words, by cutting the speed of the wind in half, the amount of sand movement can be reduced to one quarter to one eighth of the original. Physical obstacles such as windscreens (fences), vegetation, straw, bark, and rocks laid on the ground can be used for dust control. These materials absorb the momentum and reduce the speed of the prevailing wind above the ground; therefore, the amount of sand movement is reduced accordingly.

Entrapment of Faliing Sand

Falling and bouncing of particles take place when they are moved by saltation. Therefore, if particles striking the ground are trapped and 
prevented from bouncing back into the air, the amount of sand moved by this process can be reduced. To entrap the falling particles the surface of the ground $c$ an be sprayed with water or sticky materials such as adhesives. Keeping the ground surface wet(or even better, muddy) will entrap particles striking or falling on it. If the beach area of a tailings pond is always kept wet by rotating the discharging spigot of the mill waste, or by sprinkling water decanted from the pond, sand movement $c$ an be reduced. The sprinkling system can be controlled with a wind speed sensing device which activates the water sprinkle system to the beach whenever the wind speed exceeds a certain level. Tacky materials such as tar, or asphalt emuisions sprayed on the ground can also entrap falling particles; therefore, they $c$ an be used as agents for fugitive dust control.

Control of Particle Size Distribution

The saltation of tailings occurs when falling particles strike on hard surf aces such as pebbles, rocks or large particles and bounce back into the air. In this process, most of the energy is dissipated among particles rubbing each other on the ground, and a small portion of the energy is used to eject particles into the air. This is especially true when tailings particles are in a narrow size distribution. Because all ejected particles do not possess enough energy to reach a height to gain extra momentum from the wind, the chance of tailings being saltated decreases. Therefore, keeping particle size distribution in a narrow range $c$ an be considered as a method for controlling fugitive dust.

\section{Change in Surface Characteristics}

When a particle hits a hard surface, it will rebound to its original height if both the particle and the surface being hit are perfectly elastic materials. On the other hand, if the surface of the ground is treated with either physical or chemical means so that it absorbs a part or all of the energy of the falling particle, the particle will not rebound, or rebound less vigorously. Materials such as straw, geotextiles, or polymers sprayed on the ground can be used to control sand movement.

Increase in Density or Size of particles

According to the sand movement equation, increased density of particles decreases the amount of particles moved by the saltation. Although coating of particles with high density materials increases the density of the particles, this would be impractical. On the other hand, application of binding agents to agglomerate particles to form larger and thus heavier particles is another way to solve the dust problem. Agglomeration of $f$ ine particles can also prevent their movement by airborne suspension. Encrustment of particles on the ground surface by applying chemicals to create a layer of cohesive soil cover too heavy to be moved by the wind is another method of dust control. This is effective in controlling particies which are usually transported by the surface creep mechanism. 
Increase in Moisture Content

According to the sand movement flux equation (1), the water content of soil also affects the amount of sand movement; the higher the water content, the less the amount of sand moved by the wind. However, it has been reported that water can be a harmful agent in dust control, because as soon as it evaporates the soil becomes fragile and dustier. For this reason, when water is used for the dust control, the water sprinkler system must be used whenever the moisture content of the soil reaches a minimum allowable amount.

\section{Decrease of the Surface Roughness}

The height of surface roughness $Z_{0}$, as shown by equation (1) is the height above the ground where the velocity of wind is zero. This height has been found to be approximately equal to $1 / 30$ of the diameter of the grains or stones on the ground surface (Bagnold, 1954). When $Z_{0}$ approaches zero, which implies that diameters of particles are very small, then the amount of sand moved by saltation mode becomes insignificant. However, when diameters of tailings particles become very small, their chance of being transported by another mechanism - airborne suspension mode increases. Application of a cementing agent on the smoothed and compacted surface of tailings is a potentiai method for dust control. 



\section{FUGITIVE DUST CONTROL}

CONTROL METHODS

This section of the report presents the methods used to control fugitive dust as well as a discussion of industrial uses, a review of experimental programs, preliminary economics and the criteria needed to establish a suitable fugitive dust control management plan. However unl ike control methods for stationary sources, those for fugitive dust are not well documented. Therefore, several information sources were used including 1 iterature, personal interviews, test claims of proprietary chemicals, etc. A bibliography and references on control methods are included in Appendix A. There are three major methods to control fugitive dusts from tailings: physical, chemical, and biological. Combinations of these are frequently used.

\section{Physical Methods}

Wind erosion of tailings can be controlled by physical techniques, including methods which cover tailings surfaces and reduce the speed of wind impinging on them. Water sprinkling is the most simple and popular physical method being used. When water is sprayed onto the tailings surface, its surface tension holds the dust particles together and they fom a layer of wetted crust which because of its weight, prevents fine particles from being blown. This method is effective only when water supply is continuous. Once the water supply is stopped, the water in the soil evaporates and problems of fugitive dust resume.

Capping loose particles of tailings with a layer of overburden or topsoit having high cohesive forces between soil particles is also effective in controlling dust. Depending upon the tailings location, the overburden or topsoil can be obtained locally or hauled in from borrow pits located within reasonable distances.

Another physical method of dust control is covering the tailings surface with straw, bark or rocks (or gravel) which prevents direct exposure of the $f$ ines to the wind. Coverings can also act as windscreens to reduce the velocity of the wind in contact with the surface of the tailings.

Man-made films or sheets can also be used to cover tailings surfaces and thus control the dust. Nonwoven materials such as a paper fabric, HOLD-GRO $0^{(}$, and excelsior mat, EXCEL르, are a few examples commercially available. These materials usually deteriorate gradually after being exposed in the atmosphere. Because the cost of these materials is rather high they are not being used in large scale operations at the present time.

A windbreak, or a windscreen, is a dust controlling device based on the principle of a wind shadow created by an obstacle blocking the flow of the wind. When a stream of wind loaded with sand grains is blocked by such an 
obstacle, it changes the flow pattern of the wind suddenly. Directions of traveling air and sand grains after encountering the obstacle are different because of the difference in the amount of momentum carried by the mass of air and the sand grains. The air flows around the surface of the obstacle and forms two distinctive flow regimes separated by a surface of discontinuity. Outside this surface the air stream flows smoothly by; but the region below the surface of discontinuity, which is called the wind shadow of the obstacle, is filled with swirls whose average forward velocity is less than that of the air stream outside. The velocity difference disappears as the distance of the downind obstacle increases; finally the shadow fades away.

The sand grains which strike the obstacle rebound and come to rest in the relatively stagnant air in the front. They accumulate there untit they reach a maximum amount, which is limited by the sand's angle of repose and the width of the obstacle facing the wind. Any sand grains which cannot be kept in front flow over or around the obstacle. They pass through the surface of discontinuity and settle in the wind shadow where the wind velocity is lower. The amount of sand that $c$ an be accumulated behind the obstacie is also limited by the sand's angle of repose and the angle formed by the wind and obstacle surface. The length of the wind shadow in which sand grains can be accumulated as reported by Drehme1, Daniel and Carnes (1982) is related to the porosity and height of the wind screen and wind velocity. An effective dust control can be accomplished by setting up rows of windscreens, each separated by a distance shorter than the length of the wind shadow of the screen. Windscreens have been effectively used to control snowdrifts along highways and fugitive dusts from coal storage piles.

\section{Chemical Methods}

The chemical methods of dust control use chemical reagents which upon being applied onto the surfaces of tailings react either with themselves or with tailings particles to form protective films or coarse agglomerates. Thus they prevent particles from being moved by the wind. Chemical methods are effective in controlling dusts in areas where physical and biological methods are impractical because of poor accessibility, lack of soil or water, or higher cost.

Elastomeric polymers, ligninsulfonates, asphait emulsions, petroleum byproducts and hygroscopic salts are some of the chemicals used for controlling fugitive dusts. Depending upon methods of application, elastomeric polymers form either a protective film or agglomerates (or crusts) of tailings particles. A curing period is usually needed in order for an elastomeric polymer to form a permanent film or agglomerate. Timing is therefore an important factor in applying this technique to control fugitive dusts. When ligninsulfonates, asphalt emulsions and petroleum byproducts are used, they penetrate through the soil matrix, so that soil particles are glued together to form a crusty layer or a solid block which is too heavy to be picked up by the wind. Hygroscopic salts such as calcium choride or magnesium chloride absorb noisture from the atmosphere and keep the salt treated surface wet; thus they are 
often used for dust control. Because chemicals can be decomposed by oxidation or photochemical reactions and lose their dust controlling capabilities, repeated application of chemicals is usually necessary.

\section{Biologicai Methods}

Biological methods of tailings dust control are concerned with revegetation of tailings areas. Revegetation also enhances the aesthet ic value and crop production potential of the land. The following criteria should be used to select the kinds of plants for dust control: 1) plants should have the ability to thrive under existing soil, moisture and exposure conditions; 2) rapid-growing species should be chosen since they provide earlier protection; 3) plants producing the most mulch should be chosen because they control erosion best; 4) plants should be resistant to insects and diseases; and 5) plants that are poisonous to men or animals should not be used (Astrup 1951). Also, native plants have the advantage of blending in well with the surrounding environment. The actual selection of plants for revegetation may be conducted either in the laboratory or in the field.

The soil composition ( $\mathrm{pH}$, nutrient content, salinity) may need to be altered to support the veget ation, depending on the kind chosen. For example, lime, crushed limestone, asbestos mill tailings, fly ash, and sewage have been used to increase the $\mathrm{pH}$ of the soil (Leroy 1973, Dean and Havens 1973, U.S. Forest Service 1973, Ludike 1973, Peterson and Guschwind 1973, Capp and Gi imore 1973, and Skelly and Loy 1973), while pyrite-rich mill tailings, powdered sulfur and any of several acids (Leroy 1973) have been used to decrease its ph. Nutrients may be added by standard fertilizers or along with sewage sludge used for $\mathrm{pH}$ adjustment.

Revegetation is usually done by seeding or transplanting. The cost of the former is normally less. Seeding techniques include drilling, broadcasting and hydroseeding (Leroy 1973). Principal advantages of hydroseeding are: 1) it can be used to seed inaccessible sites, 2) it is a rapid method of planting disturbed areas, 3 ) it provides a more uniform coverage than most convent ional reseeding methods, 4) since the fertilizer, seed, mulch and soil amendments are all applied simultaneously, the overall cost of reseeding is reduced, and 5) the germination rate of hydroseeding is higher than that of other methods. Another method, two-step seeding, is also recommended for tajlings areas revegetation (Jones, Amizer and Bennett 1975). In this system small grain species such as barley are seeded the first year to give a quick ground cover and to produce a straw mulch into which perennial legume and grass species are interseeded the second year.

\section{INDUSTRIAL USES OF DUST SUPPRESSION TECHNOLOGY}

Dust control as a technology is receiving more and more consideration within the scope of environmental programs involving nearly all types of industries. Concern has been expressed by the Environmental Protection Agency as 
well as other Federal, state, and local regulatory agencies about the impact of open sources of fugitive dust emissions on ambient air quality standards.

Open sources are those stationary sources of air pollution too large to be controlled by enclosures or ducting. Open sources of atmospheric particles may be: industrial (surface mining and wind erosion of stock pi)es and waste piles, vehicular traffic on unpaved roads, construction site activities) or nonindustrial (agricultural activities and wind erosion of croplands, unpaved roads, and forest fires) (Kinsey et al. 1980)

In response to the problem of fugitive emissions many U.S. industries have used a variety of methods to eliminate or reduce windblown dust and its associated problems. Following are descriptions of some industries that experience fugitive dust problems, and ways they have approached solutions.

Mining Industry

Many similarities in mining, processing, and waste disposal techniques exist among the different mineral industries. Many problems associated with these techniques are also shared industry-wide. One of these is the control of open sources of fugitive dust emissions. These sources extend from strip$p$ ing and stockpiling of overburden, through mining, transporting, and milling of the ore to waste disposal and site reclamation.

Because of the large size of the disposal areas and the physical, chemical, and sometimes radiological nature of the solid wastes, the tailings piles resulting from the process are one of the worst potential sources of fugitive dust. Therefore, this review concentrates on efforts to control fugitive dust generated from the surface of tailings. However, other sources of dust and methods of control are included as well.

Much research has been done on stabilization of waste tailings for the prevention of air and water pollution, primarily by mining companies and the Bureau of Mines Metallurgy Research Center at Salt Lake City, Utah (PEDCO 1973). Radically different methods--chemical, physical, and biological--have been tested, often successfully, on inactive tailings piles. Less work has been done on active sites; the most common practice is to keep the tailings surface moist either with new deposits or by sprinkling with water.

Chemical stabilizers react with the tailings in much the same way as with other soils forning a wind-resistant crust or surf ace layer. These are difficult to apply by traditional methods due to weight limitations of the tailings pile. The chemicals, however, may be applied by automatic sprinkler systems, special light vehicles with large flotation tires, or aircraft.

Many materials have been tried to physically stabilize fine tailings. The material most often used is rock and soil from nearby areas. Soil can be a very effective cover and provides a medium for vegetation growth. However, it is not always available, and even when it is it may be too costly to apply. 
Crushed or granulated smelter slag, as well as bark and harrowing straw, have also been added into the top few inches of tailings. Once again, most of the stabilization work has been performed on inactive piles and therefore may not be applicable or cost effective for active sites. This is particularly true of many of the physical methods.

Vegetative stabilization would almost certainly be inappropriate for active tailings piles. The exception may be the face of the dam, but recontouring is usually necessary for reclamation, which would destroy any effort to establish vegetation. Several mining companies have planted old tailings piles in efforts to achieve both wind erosion control and an attractive site. Successful vegetative stabilization produces a self-perpetuating ground cover or traps and geminates native plant seeds that will grow without the need for irrigation or special care. Resistance to vegetative growth has been encountered due to excessive salts and heavy metals in the tailings, windblown sands destroying the young plants, high temperatures, and lack of water once the tailings piles drain. Recently though, several piles have been successfully planted using a combination of chemical and vegetative techniques (PEDCO, 1973). Chemicals are selected that do not inhibit growth. Once applied they minimize the problems of sandblasting and highly reflective surf aces and tend to retain moisture near the surface better.

\section{Copper Production}

A few copper producers in the western United States have rout inely used dust control techniques on such areas as haul roads. Kennecott-Salt Lake City reports having good results with some chemical stabilizers for their roads. Hygroscopic salts are popular but can be corrosive to vehic les and detrimental to roadside vegetation. Petroleum resins also work well, but can be expensive.

Some companies, independently or in conjunction with the manuf acturers of certain stabilizer products, have also tested many stabilizers on erodible portions of tailings dams with varying degrees of success (Parks and Rosene 1971). Several methods of applying the chemical stabilizers have also been demonstrated. The most pooular is usually a tank truck with a spray boom or hose and nozzle arrangement. But for areas inaccessible to ground vehicles, fixed-wing and rotary-wing aircraft have been tested.

Revegetation has been tried on both spoils and tailings piles. Spoils piles are generally inert and with fertilizer can support certain types of vegetation. Tailings are generally acidic or basic and need to be neutralized as well. With proper soil conditioning revegetation of tailings has worked well for some mines (Knudsen, Hall and Horner 1971).

\section{Molybdenum Production}

Climax Molybdenum Company in Leadville, Colorado has tested and used chemical stabilizers for more than a decade to control windblown dust on its tailings piles. Because of the mill's location, weather conditions are of ten severe and regulations governing fugitive dust are very stringent. Also, as a 
result of the milling process the tailings are highly susceptible to wind erosion. In spite of these obstacles the company has had much success with chemical stabilizers.

\section{Iron Ore Production}

Tailings are produced in large amounts at concentrators processing lowgrade taconite ores. Although the climate is not as arid in the Great Lakes region, where most of these are located, as in the western and southwestern states, population densities are often higher around the mills. Therefore control of fugitive dust from the mine and mill site is still an important task. In the period from 1976 to 1980 a University of Minnesota study was conducted for the Bureau of Mines to evaluate a variety of dust suppressants, determining their effectiveness in mitigating dust from taconite tailings. During the course of their investigation, tailings from Minnesota copper-nicke] ores were also tested with chemical binders to see how effective they were on this mineralogically different ore. Of eight chemicals tested their study indicated that Coherex, a petroleum resin emulsion, was the least costly and most durable (Yardley, LaCabanne and Nelson 1980).

Another potential source of fugitive emissions is taconite storage piles. One study conducted at Purdue University investigated the effect of watering and using chemical dust suppressants to control emissions from taconite pellet storage piles. They tested three commercially available products at very high dilution 1 part product to 1000 parts water. None of the three were very effective at this dilution. Other conclusions were that: 1) a dry taconite surface is less susceptible to wind erosion than one which has been wetted with either plain water or a diluted dust suppressant and allowed to dry, and 2) when water is used to control dust from a taconjte surface the surface, must not be allowed to dry. This lends support to other studies that have concluded that water sprinkling makes a surface more fragile and susceptible to wind erosion.

\section{Coal Production}

In coal mining operations, as with other types of mining, large amounts of dust can be generated from mining, hauling, stockpiling, crushing, grinding, and transport ation (Havens and Dean 1969). Water sprinkling is often used for dust control, but many mines are now using chemical dust suppressants to combat fugitive dust. These are particularly useful, for instance, when transporting coal over long distances in open railroad cars. Not only is fugitive dust a nuisance, but in this case in particular, wind erosion can mean the loss of a valuable product.

One study compared the relative effectiveness of chemical additives and windscreens for fugitive dust control at open coal storage piles (Drehmel and Daniel 1982). Since this is the beginning of a series of studies on dust control practices, results are preliminary. The conclusions were that chemical 
additives significantly increased the threshold velocities for fugitive dust, and that windscreens and fences effectively prevented re-entrainment of fugitive dust.

Another study of wind erosion control on coal storage piles aiso looked at chemical binders. The investigation show that a combination of both physi$c$ al and chemical methods based on a scientific approach could result in significant reductions in dust emissions from bulk storage sites (Vee) and Carr 1980).

The resuits of wind tunnel tests and studies using an open channel water flume, where flowing water is used to simulate wind, showed that shaping of the coal piles is an important factor in reducing turbulence due to sharp edges and scour action, thereby reducing entrainment of particulates. The results of the chemical binder study identified several of the materials that would be effective on coal piles and haul roads at the study site.

Uranium Production

From both chemical and physical standpoints uranium mill tailings are very similar to tailings produced by other metal extraction processes. However, because of the additional problem of radioactivity, uranium mill operators must be even more concerned with the control of fugitive dust during mining, as well as milling and disposal.

Throughout the process, from the mine to product handling and waste disposal, various means are available to maintain particulate emissions within safe levels. At the mine and on haul roads where trucks can spill ore during transportation, dust is reduced by water or sometimes chemical stabilizers such as emulsions and hygroscopic salts. At the mill open areas are treated in a similar manner, and point sources of dust emissions are controlled by enclosures and ducting where necessary.

Under nomal climatic and mili operating conditions mill operators say that tailings disposal areas can usually be operated without experiencing any serious wind erosion. Here too, the tailings are kept wet, either by water sprinkling or spigoting the tailings slurry onto the dry areas.

Water used for sprinkling is generally decanted water from the tailings pond. Evaporation from the water also aids in maintaining the water balance of the mill, since contaminated effluents cannot be allowed to run off the mill site. Another advantage of using the decanted process solutions for sprinkling is that as the water evaporates from the tailings surface, salts and minerals are concentrated and precipitated on the tailings. The precipitates of salts in many instances render the tailings more resistant to wind erosion by forming a crust over the tailings. This seems particularly true at mills using a sulfuric acid leach process. As these sulf ate bearing solutions evaporate, sulfate salts precipitate on the surface, and form a crust that is noticeably more resistant to wind than tailings surfaces without these salts. 
This is a rather fragile crust that deteriorates readily under any physical disruption such as traffic. However, if this property can be effectively utilized, it may be all that is necessary to prevent wind erosion of the tailings.

Controlled spigoting of the tailings slurry is a procedure some milis use to aid in wind erosion control. Here the wet tailings are deposited on dry areas subject to blowing. However, it is the configuration of the decant pond in the center of the dam that usually determines which spigots will be used, not which areas of the beach are drying out. Some of the process water used in the mill is recycled from the decant pond on the tailings pile. Because of the necessity for a clear water pond around the decant tower, tailings discharged to the dam require a program of spigotting to "herd" the clear water and keep it basically centered around the tower. With varying ore types, evaporation rates, and settling rates it is aimost a daily decision as to the movement of the spigot locations (Burrill and Bossard 1971). Thus it is apparent that spigoting cannot be used for dust control aione; in fact, the decision must first be the proper operation of the disposal area. Another disadvantage of this method is that as the heavier particles start to deposit near the spigot on the beach area, the slurry flow is channeled in a particular direction. As more tailings settle out, the channel created by the flow of tailings changes and meanders around the beach. Therefore, it may take at least several days before any given area becomes wetted with newly deposited tailings. This is not a very positive means of controlling dust, especially when the throughput of the mill is decreased and less tailings are being pumped to the disposal area. Decreases in mill throughput have been experi-enced at many mills recently with the worsening of the uranium market. Often under severe weather conditions neither spigoting or water sprinkling is effective in keeping the tailings from blowing.

Physical, chemical and biological procedures have been investigated as alternatives for stabilizing uranium tailings. The Bureau of Mines has been actively involved in this area of research. One such study was done at the inactive tailings site at Tuba City, Arizona (Havens and Dean 1969). Physical and biological methods were not considered because of their cost and arid climatic conditions. Successful stabilization was achieved using a relatively low-cost chemical method. Calcium lignin sulfonate was the only chemical of over 20 tested that was successful on both acid and carbonate tailings.

Department of Agriculture--Soil Conservation Service

The prevention of wind erosion has also been studied by the Department of Agriculture and its subsidiary organizations. For them, too, wind erosion usually means the loss of a valuable resource as well as production of a nuisance. Much of the tillable land in the United States is highly susceptible to wind erosion at some time of the year.

Crops are easily damaged by blowing soils, especially as seedlings. In this tender stage plants can be cut off near the surface by the abrasive action of windblown, sandy soils. A cont inuing need exists for effective, economical materials to eliminate or reduce the adverse effects of blowing soil on crops. 
Many commercially available products recommended for soil stabilization and wind erosion control have been tested by the Department of Agriculture, particularly the Agricultural Research Service in Manhattan, Kansas (Zingg and Chepil 1950, Chepil 1951, Arenbrust and Dickerson 1971). Their primary aim has been to reduce losses of soil from wind erosion. Many erosion control methods have been coimared: water sprinkling, physical barriers such as constructed wind breaks and plants, and chemical stabilizers. A secondary benef it that some chemical stabilizers provide is to enhance plant germination and energence. This enhancement is effected by the dark color of some stabilizers, raising soil temperature, and by the ability of the treated soils to retain moisture better than untreated ones.

Highway Construction Industry

The types of soil encountered combined with certain weather conditions during construction of highways are oftentimes conducive to extensive dust generation, especially in the more arid regions. Dust becomes a serious hazard to traffic, is a nuisance to nearby residential areas, and increases the cost of equipment maintenance. In addition, unpaved gravel secondary roads require periodic grading and replacement of material lost through erosion due to traf$f i c$ and wind. Dust aiso presents a potential health hazard for men working at the construction sites.

One investigation of soil erosion control conducted at the Arizona Traf $f i c$ and Transportation institute, University of Arizona, looked at 46 commercially available chemicals (Suiton 1976). Sponsors of the study were the Arizona Department of Transportation and the Federal Highway Administration, U.S. Department of Transportation. The objective of the study was to ident ify chemicals that would be effective in limiting wind erosion on soils used for road construction and that would be durable when subjected to traffic. Based on results of laboratory and field tests, a few of the chemicals successfully reduced erosion under traffic on an unpaved road.

The most common method of dust control in the highway construction industry has been, and in most instances continues to be, the use of water applied as often as necessary. Under certain cincumstances, however, this cannot be done frequently enough to eliminate the problem, and may in fact aggravate the problem (Canessa 1971).

On many new highway construction projects various companies and agencies have compared the effectiveness and costs of a number of chemical stabilizers with that of water sprinkling. Results have shown in some cases chemical dust suppressants are superior in tems of effectiveness and less expensive than water sprinkling.

Electric Utilities

The burning of coal has been cited as causing more air pollution than other forms of power generation (Kalika and Catizone 1980). Among the serious concerns are fugitive emissions of particulate matter as sources of air 
poliution. At most coal-fired power plants huge uncovered stockpiles of finely ground coal are kept to feed the boilers. Because of their fine, unconsolidated nature and relatively low density, these stockpiles are subject to potentially severe wind erosion -an unsightly nuisance, a potential heaith hazard, and loss of a valuable material.

To reduce fugitive emissions from these stockpiles, utility companies have investigated and are using various methods of dust suppression. Most common is keeping the oile wet by spraying chemical stabilizers onto the surface or putting up windscreens (fences of open woven material that disrupt the wind flow) (Dretmel and Daniel 1982).

The Mi i itary

Various branches of the military have need of soil stabilizing systems capable of effective dust control and soil waterproofing. Dust control is especially important for military roads and around military airports and heliports in the theater of operations (Kozan and Stouffer 1970). The majority of this work has been done by or under contract to the U.S. Army Engineers at the Waterways Experiment Station, Vicksburg, Mississippi. An example is a study conducted by the Armour Industrial Chemical Company in the late 1960s (Armour 1978). They looked at combinations of bituminous and resinous materials (asphalt products) for use as dust palliatives. Results indicated those which showed the most potential to satisfy Department of the Army requirements for dust suppressants were based on cationic asphalt emulsions. As well as dust control, these materials increased the load-bearing ability of the soil and decreased its water permeability, which are also desirable properties.

In general, the fugitive dust control methods used by a1] industries were applications of one of three basic techniques-watering, chemical stabilization, or reduction of surface wind speed across exposed sources. Watering is generally initially a low-cost method, but provides only temporary dust control. Depending on the nature of the dust source and climatic conditions, water may be an effective dust suppressant for only a few hours or for several days. In addition to the direct cohesive force of a film of moisture, watering may also create a thin surface crust that is more compact and mechanically stable than the material below and al so less subject to dusting even after drying. However, this crust and its dust-reducing capability are easily destroyed by movement on the surface or by abrasion from loose particles blown across the surface. Therefore, the watering must be repeated frequently to reform the moisture film or surface crust.

It should be pointed out that the fugitive dust problem is accentuated in uranium tailings regions primarily because the local climate is often arid and soil lacks natural surface moisture. As a corollary to this, water is a scarce resource in these areas, and may not be readily available as a fugitive dust control material. 
Several types of chemicals have been effective in reducing dusting when applied on fugitive dust sources. These chemicals act by several different means and are generally categorized by their composition--bituminous, polymer, resin, enzymatic, emulsion, surface-active agent, ligninsulfonate, latex, etc. It is estimated that over 100 chemical products are presently marketed or are under development specifically as dust control agents. Infomation was collected during the present study for those products is shown in Table 3 .

With the wide range of dust control characteristics available in commercial products, a chemical stabilizer can be selected to suit each dust control application. Some of the materials can "heal" if the treated surface is disturbed, but many will not reform. The life of the treated surface under natural weathering also varies widely with different chemicals. Selection of the appropriate material may require that several other criteria be checked for compatibility: application method, possible contamination of recycled process water, and correct chemical for texture of specific soil or material. Although no single comprehensive summary of dust suppressant chemicals and their properties was found, several evaluations have been prepared for different chemicals on a single type of fugitive dust source. These are discussed in the following section.

Reducing surface wind speed across the fugitive dust source may be accomplished with windscreens or windbreaks, enclosures or coverings for the sources, and planting of tall grasses or grains on or adjacent to exposed surfaces. The vegetative techniques all need a soil which contains growthcontaining nutrients, moisture, and has the proper texture. These requirements, especially adequate moisture, are often not present in uranium mill tailings areas and may be the reason that natural protection against wind erosion is insufficient. The size and location of most of the fugitive dust source on a $U$ tailings pile make physical enclosures or wind barriers impractical.

REVIEW OF SELECTED EXPERIMENTAL PROGRAMS RELATED TO FUGITIVE DUST CONTROL

Dust suppressants have been applied by industries to stabilize soil, sand, coal dust and powder products. Many reports evaluating dust suppressants are available in the literature. In this section, methods for evaluation of chemi$c$ al suppressants for four applications typically selected from the literature will be briefly reviewed. This will help us develop a systematic method to evaluate chemical suppressants for fugitive dust control in uranium taijings. The dust suppressants are used in the following cases for soil stabilization of fanm lands, sand dunes, taconite tailings and coal dust control.

Soil Stabilization for Agricultural Purposes

Armbrust and Dickerson (1971) used four criteria to evaluate 36 commercially available dust suppressant materials. The suppressants must: 1) cost less than $\$ 50$ per acre, 2) prevent erosion initially and reduce it for at least two months, 3) not reduce plant germination and growth, and 4) be able 


\section{TABLE 3. Potential Chemical Stabilizers for Use on Uranium Mill Tailings}

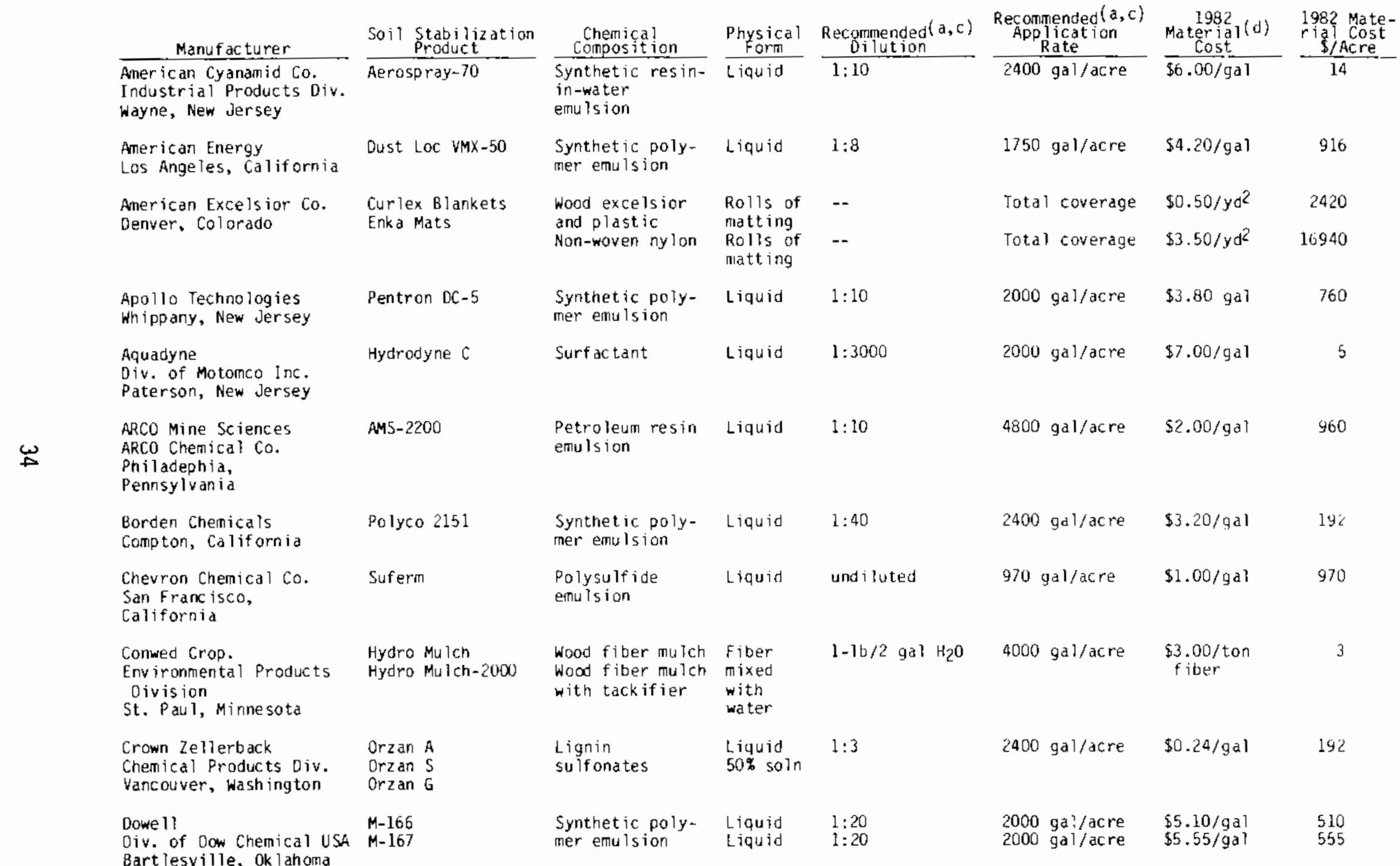

(a) Recomended by manufacturer.

(b) Diluted with water.

(c) Recomended application of diluted solution.

(d) Costs are estinated FOB-Casper/Riverton, WY for Concentrate. 


\section{TABLE 3. (contd)}

\begin{tabular}{|c|c|c|c|c|c|c|c|}
\hline Manuf ac turer & $\begin{array}{l}\text { Soll Stabilization } \\
\text { - Product }\end{array}$ & $\begin{array}{c}\text { Chemical } \\
\text { Composition }\end{array}$ & $\begin{array}{l}\text { Physical } \\
\text { Form }\end{array}$ & $\begin{array}{l}\text { Recommended }(a, c) \\
\text { Dilution }\end{array}$ & $\begin{array}{l}\text { Recommended }(a, c) \\
\text { Application } \\
\text { Rate }\end{array}$ & $\begin{array}{l}1982 \\
\text { Materiaf }(d) \\
\text { Cost }\end{array}$ & $\begin{array}{l}1982 \text { Mate- } \\
\text { rial Cost } \\
\$ / \text { Acre }\end{array}$ \\
\hline $\begin{array}{l}\text { E. F. Houghton \& Co. } \\
\text { Valley Forge, } \\
\text { Pennsylvania }\end{array}$ & Rezosol $5411-8$ & $\begin{array}{l}\text { Synthet ic poly- } \\
\text { mer emulsion }\end{array}$ & Liquid & $1: 30$ & $1750 \mathrm{gal} / \mathrm{acre}$ & $\$ 6.30 / \mathrm{gal}$ & 367 \\
\hline $\begin{array}{l}\text { Energy Systems } \\
\text { Mc. Lean, Virgina }\end{array}$ & $\begin{array}{l}\text { Sandstill } \\
\text { Sandstill Il }\end{array}$ & $\begin{array}{l}\text { Petroleum resin } \\
\text { based emulsions }\end{array}$ & Liquid & $1: 10$ & 2400 gal/acre & $\$ 3.00 / 9$ al & 720 \\
\hline $\begin{array}{l}\text { Environmental } \\
\text { Stabilizers } \\
\text { International } \\
\text { Tacoma, Washington }\end{array}$ & ESI-Bond & $\begin{array}{l}\text { Water- } \\
\text { soluble }\end{array}$ & Liquid & $1: 2$ & $900 \mathrm{ga} 1 / \mathrm{acre}$ & $\$ 4.75 /$ gal & 8 \\
\hline $\begin{array}{l}\text { ESCHEM } \\
\text { Div. of Swift Co. } \\
\text { Chicago, lllinois }\end{array}$ & $T P C-2245$ & $\begin{array}{l}\text { Technical pro- } \\
\text { tein colloid }\end{array}$ & Liquid & $1: 5$ & $450 \mathrm{gal} / \mathrm{acre}$ & $\$ 4.80 / 9 a T$ & 432 \\
\hline $\begin{array}{l}\text { General Analine and } \\
\text { Filil Corp. } \\
\text { Chemjcal Products Div. } \\
\text { ivew York, New York }\end{array}$ & $\begin{array}{ll}\text { Gantrez } & \text { AN-119 } \\
\text { Gantrez } & \text { AN-139 } \\
\text { Gantrez } & \text { AN-169 }\end{array}$ & $\begin{array}{l}\text { Water-soluble } \\
\text { polymers }\end{array}$ & Powders & $1: 50 \quad\left(\mathrm{Hot}_{2} \mathrm{O}\right)$ & $2400 \mathrm{gal} / \mathrm{acre}$ & $\$ 2.65 / 10$ & 127 \\
\hline $\begin{array}{l}\text { Great Salt Lake Minerals } \\
\text { and Chemicals } \\
\text { biv. of Gulf Resources } \\
\text { and Chemicals } \\
\text { ogden, Utah }\end{array}$ & Oust Gard & $\begin{array}{l}\text { Magnesium chlo- } \\
\text { ride brine }\end{array}$ & $\begin{array}{l}\text { Liquid, } \\
34 \% \text { soln }\end{array}$ & undiluted & $2400 \mathrm{gal} / \mathrm{acre}$ & $\$ 0.38 / 9 a !$ & 912 \\
\hline $\begin{array}{l}\text { Hercules } \\
\text { Portland, oregon }\end{array}$ & Hercobind DS-3 & $\begin{array}{l}\text { wood processing } \\
\text { byproduct }\end{array}$ & Liquid & $1: 10$ & $500 \mathrm{gal} / \mathrm{acre}$ & $\$ 2.00 / \mathrm{gal}$ & 100 \\
\hline $\begin{array}{l}\text { Johnson and March Corp. } \\
\text { Philade lphia, } \\
\text { Pennsylvania }\end{array}$ & $\begin{array}{l}S P-301 \\
S P-400\end{array}$ & $\begin{array}{l}\text { Synthetic poly- } \\
\text { mer emulsions }\end{array}$ & $\begin{array}{l}\text { Liquid } \\
\text { Liquid }\end{array}$ & $\begin{array}{l}\text { und i luted } \\
\text { und i luted }\end{array}$ & $\begin{array}{l}450 \mathrm{gal} / \mathrm{acre} \\
450 \mathrm{gal} / \mathrm{acre}\end{array}$ & $\begin{array}{l}\$ 2.65 / \mathrm{gal} \\
\$ 4.45 / \mathrm{gal}\end{array}$ & $\begin{array}{l}1193 \\
2002\end{array}$ \\
\hline $\begin{array}{l}\text { Morton Chemical Co. } \\
\text { Chicago, Illino is }\end{array}$ & Liquid Dust Layer & $\begin{array}{l}\text { Magnesium car- } \\
\text { bonate or ine }\end{array}$ & Liquid & und iluted & $2400 \mathrm{gal} / \mathrm{acre}$ & $\$ 0.80 / \mathrm{gal}$ & 1920 \\
\hline $\begin{array}{l}\text { NALCO Chemical Co. } \\
\text { Salt Lake City, Utah }\end{array}$ & $\begin{array}{l}8820 \\
8803 \\
\text { IDA-656 }\end{array}$ & $\begin{array}{l}\text { Synthet ic poly- } \\
\text { mer enulsions }\end{array}$ & Liquids & $\begin{array}{l}1: 20 \\
1: 50 \\
1: 200\end{array}$ & $\begin{array}{l}520 \mathrm{gal} / \mathrm{acre} \\
450 \mathrm{gal} / \mathrm{acre} \\
1750 \mathrm{gal} / \mathrm{acre}\end{array}$ & $\begin{array}{l}\$ 5.40 / \mathrm{gal} \\
\$ 8.20 / \mathrm{ga} 1 \\
\$ 8.50 / \mathrm{gal}\end{array}$ & $\begin{array}{r}140 \\
74 \\
74\end{array}$ \\
\hline $\begin{array}{l}\text { National filter Media } \\
\text { Salt Lake City, Utah }\end{array}$ & Fabric 22410098 & $\begin{array}{l}\text { Polypropylene } \\
\text { geotextile }\end{array}$ & $\begin{array}{l}\text { Rolls of } \\
\text { fabric }\end{array}$ & NA & Total coverage & $\$ 0.30 / y \mathrm{~d} 2$ & 1452 \\
\hline \multicolumn{8}{|c|}{$\begin{array}{l}\text { (a) Recommended by manufacturer. } \\
\text { (b) Diluted with water. } \\
\text { (c) Recommended application of diluted solution. } \\
\text { (d) Costs are estimated FoB-Casper/Riverton, WY for Concentrate. }\end{array}$} \\
\hline
\end{tabular}


$\underline{\text { TABLE } 3 .}$ (contd)

\begin{tabular}{|c|c|c|c|c|c|c|c|}
\hline Manufacturer & $\begin{array}{c}\text { Soil Stabilization } \\
\text { Product } \\
\end{array}$ & $\begin{array}{l}\text { Chenical } \\
\text { Composition }\end{array}$ & $\begin{array}{l}\text { Physical } \\
\text { Form } \\
\end{array}$ & $\begin{array}{l}\text { Recommended }(a, t) \\
\text { Dilution }\end{array}$ & $\begin{array}{l}\text { Recommended }(a, c) \\
\text { Application } \\
\text { Rate }\end{array}$ & $\begin{array}{c}1982 \\
\text { Material } \\
\text { Cost } \\
\end{array}$ & $\begin{array}{l}1982 \text { Mate- } \\
\text { rigi Cost } \\
\$ / \text { Acre }\end{array}$ \\
\hline $\begin{array}{l}\text { Phillips Fibers } \\
\text { Phillips Chemical co. } \\
\text { Greenville, } \\
\text { South Carolina }\end{array}$ & SUPAC, PETROMET & $\begin{array}{l}\text { Polypropylene } \\
\text { geotextile }\end{array}$ & $\begin{array}{l}\text { Ralis of } \\
\text { fabric }\end{array}$ & NA & Total coverage & $\$ 0.60 / y d^{2}$ & 2904 \\
\hline $\begin{array}{l}\text { Reclamare Co. } \\
\text { Seattle, Washington }\end{array}$ & $\begin{array}{l}\text { J-Tac } \\
\text { Marloc }\end{array}$ & $\begin{array}{l}\text { Natural plant } \\
\text { gum tacifier } \\
\text { Synthet ic poly- } \\
\text { mer emulsion }\end{array}$ & $\begin{array}{l}\text { Powder } \\
\text { Liquid }\end{array}$ & $\begin{array}{l}\text { To viscous } \\
1 \text { iquid } \\
1: 16\end{array}$ & $\begin{array}{l}120 \text { lb powder } / \\
\text { acre } \\
3000 \text { ga } 1 / \text { acre }\end{array}$ & $\begin{array}{l}\$ 3.40 / 1 b \\
\$ 3.60 / g a l\end{array}$ & $\begin{array}{l}408 \\
675\end{array}$ \\
\hline $\begin{array}{l}\text { Reichold Chemicals, Inc. } \\
\text { South San Francisco, } \\
\text { California }\end{array}$ & Wallpol 40-133 & $\begin{array}{l}\text { Synthetic poly- } \\
\text { mer emulsion }\end{array}$ & Liquid & $1: 5$ & $450 \mathrm{gal} / \mathrm{acre}$ & $\$ 2.70 / 9 a 1$ & 243 \\
\hline $\begin{array}{l}\text { Union Carbide Corp. } \\
\text { Terrytown, New York }\end{array}$ & Dust Binder 266 & $\begin{array}{l}\text { synthetic poly- } \\
\text { mer emuision }\end{array}$ & Liquid & $1: 20$ & $2.400 \mathrm{gal} / \mathrm{acre}$ & & \\
\hline $\begin{array}{l}\text { Walsh Chemicals } \\
\text { Philadelphia, } \\
\text { Pennsylvania }\end{array}$ & Soil Gard & $\begin{array}{l}\text { Synthetic poly- } \\
\text { mer enulsion }\end{array}$ & Liquid & $1: 15$ & $1300 \mathrm{gal} / \mathrm{acre}$ & $\$ 3.60 / 9$ a 1 & 312 \\
\hline $\begin{array}{l}\text { Wedco Products } \\
\text { Los Angeles, California }\end{array}$ & $V-4100$ Binder & $\begin{array}{l}\text { Synthetic poly- } \\
\text { mer emulsion }\end{array}$ & Liquid & $1: 8$ & 450 gal/acre & $\$ 6.00 / 9 a 1$ & 337 \\
\hline $\begin{array}{l}\text { Wen Don Corp. } \\
\text { Price, Utah }\end{array}$ & CPB-12 & $\begin{array}{l}\text { Synthet ic poly- } \\
\text { mer emulsion }\end{array}$ & Liquid & $1: 10$ & $2400 \mathrm{gal} / \mathrm{acre}$ & $\$ 3.04 / 9 a 1$ & 874 \\
\hline $\begin{array}{l}\text { Weyerhaeuser Co. } \\
\text { Wood Products Div. } \\
\text { Tacoma, Washington }\end{array}$ & Silva Fiber & $\begin{array}{l}\text { Wood fiber } \\
\text { mulch }\end{array}$ & $\begin{array}{l}\text { Fiber } \\
\text { mixed } \\
\text { with } \\
\text { water }\end{array}$ & $\begin{array}{l}1 \text { lo fiber } / \\
? \text { gal } \mathrm{H}_{2} \mathrm{O}\end{array}$ & $4000 \mathrm{gal} / \mathrm{acre}$ & $\begin{array}{l}\$ 225 / \text { ton } \\
\text { fiber }\end{array}$ & 225 \\
\hline $\begin{array}{l}\text { Witco Chemical Co. } \\
\text { Golden Bear Div. } \\
\text { Bakersfield, California }\end{array}$ & Conerex & $\begin{array}{l}\text { Petroleum resin } \\
\text { emulsion }\end{array}$ & Liquid & $I: 5$ & $2400 \mathrm{gal} / \mathrm{acre}$ & $\$ 1.25 / 9 a 1$ & 600 \\
\hline
\end{tabular}

(a) Recomended by manufacturer.

(b) Diluted with water.

(c) Recomended application of diluted solution.

(d) Costs are estimated FOB-Casper/Riverton, WY for Concentrate. 
to be applied easily. They used a highly wind-erodible soil containing $89.6 \%$ sand, $5.9 \%$ silt and $4.5 \%$ clay that has particle sizes less than 0.25 in. Soil samples in trays were hand-sprayed with stabilizing materials at different application rates and dilution ratios. The treated samples were exposed to a $30-m p h$ wind in a wind tunnel for $10 \mathrm{~min}$. The effectiveness of the dust suppressant was measured by the amount of soil blown by the wind. They also conducted weathering tests by exposing the treated samples to the atmosphere (outdoor) for 60,120 , and 180 days. Growth and emergence tests of plants (tomatoes and green beans) were also conducted. From these tests and criteria mentioned above, Ambrust and Dickerson concluded that six materials (one as a resin in-water emulsion, others as liquid polymers) were acceptable: Coherex ${ }^{\circledR}$, DCA-70 $0^{\circledR}$, Petroset $S B^{\circledR}$, Polyco $2460^{\circledR}$, PolyCo $2605^{\circledR}$, and SBR Latex-2105

\section{Coal Industry}

The second experimental program to be discussed is the use of dust control agents in the coal industry. In a report written by Drehmel, Daniel and Carnes (1982), the effectiveness of chemical additives and windscreens for fugitive dust control (dust control) was evaluated. After being treated with chemicals and dried overnight, coal dusts in a sample-holding pan were put into a wind tunnel for the effectiveness evaluation.

Each chemical's effectiveness was measured by the weight loss of the sample subjected to various wind velocities. The maximum test velocity of the wind selected was the rate at which the weight loss of the sample was equal to $10 \mathrm{~g} / \mathrm{min}$. Ten chemical additives were evaluated. Their chemical constituents include dimethy idicocoammonium organic salts, oils, acrylics, synthetic polymers, or copolymers. Two types of coal dusts with median diameters differing by a factor of 3 were used in the study. The supplier-recommended application rates and dilution ratios were used to prepare the samples. Results of the wind tunnel tests showed that with or without additives, the entrainment rate rises rapidly with wind velocity and that increasing the amount of additive increases the threshold velocity. They also found that entrainment rate varies inversely with entrainment velocity.

Their evaiuation showed that cost varies over four orders of magnitude with Coal Dyne ${ }^{\circledR}$ and $\mathrm{SP}-301^{\ominus}$; all but Coal Dyne ${ }^{\circledR}$ appeared to be effective at the manufacturer's recommended rate. In comparing the entrainment factor at a standard cost of $\$ 750 /$ hectare, the most cost-effective additives are lignosulfonate, oil and water, Coal Dyne ${ }^{\circledR}$, and Polyco $2151^{\circledR}$. Of this group, Polyco $2151^{\circledR}$ was also effective when applied at a cost of $\$ 168 /$ hectare. The effectiveness of a chemical additive in water varies dramatically according to the extent of dilution, the application rate, and method of application. Moreover, the optimum conditions for one additive are often not those of another. Also, they concluded that merely using more additive may not solve the problem and that the most cost-effective application rate cannot be assumed but must be found by experimenting. 
Taconite Tailings

Mitigation of dust from taconite tailing was studied by Yardley, Lacabanne and Nelson of the University of Minnesota (1980). They conducted both field and laboratory wind tunnel tests to evaluate the effectiveness of some commercially available dust suppressants (Coherex ${ }^{(2)}$, Trex-lta ${ }^{(2)}$, sodium silicate, S-3018, and Gelguard ${ }^{8}$ ). These were applied to taconite tailings in different strengths and different combinations. The field tests were conducted in 75 test plots. They lasted for eight months through freeze, thaw, snow, ice and wind cycles. Coherex and sodium silicate survived well throught the winter and part of spring; the rest of the suppressants were less effective. Most combinations of these suppressants survived the winter weathering. In laboratory tests suppressant treated samples were exposed to a 40-mph wind. The effectiveness of dust mitigation was measured by weight loss of the sample and the direct dust emission measured by a dust-counting instrument (Royco 281). It was found that for untreated coarse tailings, wind picked up most of the dust in the first fraction of a minute. Compared with an untreated samples Coherex and Trex-1ta ${ }^{(B)}$ reduced weight loss to $4.3 \%$ and less than $1 \%$, respectively. When a tailings sample was sprayed with water, the fine particles were washed down into the interstices between the coarse particles; therefore, water could be used as a dust controlling agent. When a suppressant was applied to tailings of fine particles, it had to cover the tailings surface; otherwise, wind would blow particles from the bare spots, undercutting the protected surface and creating severe dusting problems. Tests showed that applying Coherex and Trex-lta did not affect the percolation rate. Finally, with wind tunnel tests on samples of $\mathrm{Cu}-\mathrm{Ni}$ tailings, dust supressants reduced fugitive dust by better than $99 \%$.

\section{Highway Constructions}

H. A. Sultan of University of Arizona (1974) in a project sponsored by the Arizona Department of Transportation evaluated the effectiveness of 46 commercially avajlable dust controlling agents for the control of soil erosion due to wind and traffic. The criteria for the evaluation were: cost, ease of application and durability in the field. Sultan used Yuma sand (0.1 to $0.3 \mathrm{~mm})$ and granitic soil in samples. (The latter was used for the study of effects of traffic only.) Laboratory tests included subjecting specimens of a dune sand, treated with spray-on chemicals, to wind velocities up to 90 mph. Specimens of compacted granitic soil treated with either a spray-on or mixed-in chemical were subjected to traffic forces under simulated tire pressures up to 60 psi. Samples with chemical treatments were subjected to various environmental conditions (freeze-thaw cycles, wet-dry cycles, rainfall-dry cycles, and curing temperature variation) before the evaluation tests. After durability and $90-$ mph wind tests 14 out of the 46 chemicals tested controlled the erosion to $5 \%$ of the control sample without chemical treatment. Lignin-based products suppressed dust quite well; however, they can be leached out by water and lose their effectiveness. Adding combinations of waterproof ing material such as Formula-125 (sodium methyl siliconate) to the lignin products could improve the effectiveness even when samples are subjected to the rain-dry cycle. The report stated that if there is no cost limitation, some chemicals can be considered effective if their application rates are increased. 
CRITERIA FOR SELECTION OF DUST CONTROL METHOD

Effectiveness and practicability are the primary criteria to be used for selecting techniques for stabilization of uranium tailings.

\section{Effectiveness}

A dust control method must be both cost effective and technically effective. Cost effectiveness is one of the important factors in evaluating available dust stabilizing techniques. Dollars per unit area $(\$ /$ acre $)$ of tailings being treated is a common unit for comparison. Treatment cost should include the material, site preparation, application and labor costs, etc.

Technical effectiveness means efficiency in dust control, including the range of particle size which can be controlled and changes in controi efficiency due to $\mathrm{climatic}$ variations. Dust control can be measured by the percent of weight loss from treated tailings compared with that of untreated tailings. Wind tunnel tests using carefully controlled wind velocities and flow patterns can provide such a measurement. The wind tunnel must simulate the prevailing wind conditions at the tailings site where the stabilizing technique will be used. This simulation must be as close as possible to the real situation in order to obtain useful information. Some dust control techniques work effectively over only a certain range of particle sizes. Since the distances that particles can be carried by the wind depend on their size and density, the particle size factor of the tailings must also be included when evaluating control techniques.

Changes in effectiveness of a stabilization technique because of weathering is also important in evaluating the technique. The effects of weathering due to sun, rain, snow, wind, freezing, and thawing, etc., can be simulated in the laboratory.

Durability is a function of the effectiveness of most stabilization techniques, and decreases with time because of exposure of treated tailings to the atmosphere where oxidation and/or photochemical reactions nay take place. If a stabilization technique is effective for only a short period, repetitive applications of the material will be necessary. This, in turn, increases the cost of dust control. On the other hand, in the case of intermittent disposal of mill wastes at an active tailings site, a short-duration dust stabilization technique (compared with the control technique used for an inactive site) may well be the best choice.

\section{Practicability}

In selecting a dust control technique, practicability must also be considered. Practicability means that materials used for dust control must be readily available, have a long shelf life, and be easy to apply. Also, the treated tailings must be relatively permeable to water, and chemicals detrimental to mili recovery circuits must be avoided. 
The manufactured materials or topsoil used for tailings stabilization must be readily available in large quantities. If topsoil is used, it must be obtained from borrow pits within reasonable distances to minimize the transportation cost.

If, however, only a limited quantity of the stabilization material can be supplied by a manufacturer, the purchase-and-storage method must be considered. In this situation, the shelf life of the material becomes an important criterion in selecting a stabilizing technique. Stockpiling the material not only solves the supply problem, it also provides for an emergency situation.

The stabilization agents can be applied on the surface of tailings or blended into the matrix of the top layer of tailings. Physical and chemical properties of the agents can affect the method of application. For example, a dust controlling agent with a low viscosity can be applied by a sprayer directly; however, an agent with a high viscosity must be heated or diluted to reduce its viscosity before it can be sprayed. In selecting a dust control technique use of expensive, specially designed equipment to apply the agent should be avoided.

Because of intermittent disposal of mill wastes, a tailings pile is usually built of layers of sands and slimes. The dust control agent is applied to the surface of each layer to control tailings loss, because saturation of the embankment soil of a tailings pond with water could cause dam failure, the surface of tailings treated with the dust-controlling agent should nave good pemeability. Also, because water in tailings ponds is usually recycled, any dust-controlling agents which result in leachates detrimental to the mill recovery system should not be used.

Any tailings stabilization technique must be environmentally acceptable. An ideal stabilization technique should use non-toxic, non-corrosive and nonflammable materials.

Chemicals used for dust control should not be harmful to those applying the stabilizer. Chemical agents with potential toxic chemicals should not be used if they are taken up by plants and go into the food chain of animals and human beings. Leaching of these chemicalis should not contaminate surface or ground water.

The ultimate purpose of the interim stabilization of uranium tailings is to control fugitive dust problems for a period of months up to the time a permanent stabilization technique is available; therefore, methods selected for the interim stabilization purpose should not add any burden to any future stabilization process. 


\section{REGU ATIONS AND STANDARDS FOR FUGITIVE DUST CONTROL}

The U.S. Environmental Protection Agency (EPA) promulgated "Environmental Radiation Protection Standards for Nuclear Power Operations" (40 CFR 190), which provides 1 imits for radiation doses received by the public as a result of nuclear fuel cycle operations. Effective December 1, 1980, each uranium milling facility is instructed to conduct its operations in a manner that assures that the annual radiation dose equivalent of 25 mrems to the whole body, 75 mrems to the thyroid and 25 mrems to any other organ of any member of the public is not exceeded. (However, the dose from radon and its daughters is excluded.) In order to comply with these standards, the NRC prepared an amendment to 10 CFR 20 which requires that NRC licensees comply with $40 \mathrm{CFR} 190$. This regulation requires strict emission controls at the mill.

The NRC amended its regulations to specify licensing requirements for milling activities including tailings and other waste generation. The amendments to 10 CFR 40 ("Domestic Licensing of Source Material") took into account the conclusions reached in the final generic enviromental impact statement (GEIS) on uranium milling (NUREG-0706) and the requirements mandated in the Uranium Mill Tailings Radiation Control Act of 1978. The major conclusion reached in the final GEIS that relates to dust control is stated in Section IV, Paragraph 6 of 10 CFR 40, October 3, 1980:

"6. Milling operations should be conducted so that all airborne effluent releases are reduced to as low as is reasonably achievable. To accomplish this objective, staged reclamation of tailings systems should be considered to control radon emissions and the blowing of dusts from tailings, and frequent determinations of the performance of emission control devices should be made to ensure that the se devices are operating at anticipated efficiencies."

As part of the amendment, an Appendix A was added to 10 CFR 40 and is entitled, "Criteria Relating to the Operation of Uranium Mills and the Disposition of Tailings or Wastes Produced by the Extraction or Concentration of Source Material from Dres Processed Primarily for Their Source Material Content." The technical criteria that relates to fugitive dust control is stated below in Criterion 8 .

"Criterion 8--Milling operations shall be conducted so that ali airborne effluent releases are reduced to levels as low as is reasonably achievable. The primary means of accomplishing this shall be by means of emission controls. Institutional controls, such as extending the site boundary and exclusion area, may be employed to ensure that offsite exposure limits are met, but only after all practicable measures have been taken to control emissions at the source. Notwithstanding the existence of individual dose standards, strict control of emissions is necessary to assure that population exposures are reduced to the maximum extent reasonably achievable 
and to avoid site contamination. The greatest potential sources of offsite radiation exposure (aside from radon exposure) are dusting from dry surfaces of the tailings disposal area not covered by tailings solution and emissions from yellowcake drying and packaging operations . . . To controi dusting from tailings, that portion not covered by standing liquids shall be wetted or chemically stabjlized to prevent or minimize blowing to the maximum extent reasonably achievable. This requirement may be relaxed if tailings are effectively sheltered from wind, such as may be the case where they are disposed of below grade and the tailings surface is not exposed to wind. Consideration shall be given in planning tailings disposal prograns to methods which would allow phased covering and reclanation of tailings impoundments since this will help in controlling particulate and radon emissions during operation. To control dusting from diffuse sources, such as tailings and ore pads where automatic controls do not apply, operators shall develop written operating procedures specifying the methods of control which will be utilized.

Criterion 8A--Daily inspections of tailings or waste retention systems shall be conducted by a qualified engineer or scient ist and documented. The appropriate NRC regional off ice as indicated in Append ix D of 10 CFR Part 20, or the Director, Office of Inspection and Enforcement, U.S. Nuc lear Regulatory Comission, Washington, D.C. 20555, shall be immediately notified of any failure in a tajlings or waste retention system which results in a release of tailings or waste into unrestricted areas, and/or of any unusual conditions (conditions not conterplated in the design of the retention system) which if not corrected could indicate the potential or lead to failure of the system and result in a release of tailings or waste into unrestricted areas."

Another standard that relates to fugitive dust control is the National Primary Ambient Air Quality Standards (40 CFR 50), part of the Clean Air Act. These national standards for particulate matter measured by the reference EPA method or by an equivalent method are: a) $75 \mu \mathrm{g} / \mathrm{m}^{3}$ annual geometric mean and b) $260 \mathrm{\mu g} / \mathrm{m}^{3}$ maximum 24-h concentration not to be exceeded more than once per year.

Other standards that might relate to fugitive dust control may be found in the Resource Recovery and Conservation Act (RCRA).

\section{PRELIMINARY COST ANALYSIS}

This section provides an analysis of the cost of controlling fugitive dust emissions from uranium mill tailings. Included are site preparation, material and application costs, as well as a brief sensitivity analysis (the effects of application rate, expected life of stabilizer, etc). The total 
cost of interim stabilization of all tailings piles is not included, however, since cost effectiveness is site specific. Therefore, the costs are estab1 ished for a hypothetical case in terms of $\$ / 100$ acres/yr.

The hypothetical uranium mill tailings pile was assumed to be 100 acres in size, and nearly flat on top, with a minimum of site preparation required. Cost data used to estimate the average costs of interim stabilization (1982 dollars) are presented in Table 4.

In Table 3 amounts of suppressant required per 100 acres were calculated based on manufacturers' recommended applications. From these values and the unit prices of suppressants quoted by manuf acturers F.0.B. at a Wyoming uranium mill tailings site, the material cost $(\$ / 100$ acre) for the hypothetical case was also calculated and listed in the table. The costs of the suppressants range from $\$ 471 / 100$ acre for Hydrodyne $C^{(8)}$ to $\$ 193,800 / 100$ acre for $S P-400^{8}$.

The cost of fugitive dust control from uranium mill tailings for the hypothetical case includes site preparation, application, material and monitoring-maintenance costs. The site preparation includes contouring and watering of the site. Usually the tailings pile is rather flat, except for a $f$ ew channeis carved by the flow of mill wastes when they are discharged from spigots. This contouring work is believed to be very minimal and is done by a blade or scraper to create a relatively flat surface on which the suppressant can be applied. To prevent tailings from being blown away by the wind during the contouring period, water is sprayed on the surface of the tailings. Costs of contouring and watering described in this study are estimatd at $\$ 10 /$ acre and $\$ 5 /$ acre/day, respectively.

The solution suppressant is applied by a water truck with a spray bar or a portable spray sytem. It is est imated that this can be carried out by an operator with help from the truck driver. The hourly charge rate of an operator is $\$ 30 / \mathrm{hr}$ and the truck rental (including equipment and driver) is $\$ 50 / \mathrm{hr}$. It is also assumed that it takes eight hours to spray the suppressant onto the hypothetical tailings pile of 100 acres.

Material costs 1 isted previously in Table 3 will be used directly in this cost analysis. For monitoring and maintenance, we assumed that one man-shift per month is needed to take data and do maintenance work at the stabilized site. The hourly charge rate is again assumed as $\$ 30 / \mathrm{hr}$.

For an active tailings pile it was assumed that at any one time, onequarter of the hypothetical area (i.e., 25 acre) is covered by slurry discharged from the mill and the area wetted by the slurry is rotated according to the effective life of the dust suppressant ( $t$ imes between two consecutive applications). However in many cases the spigoting is determined by the need to keep the decant pond around the decant tower. Due to the lack of reliable data, the life or effectiveness of the suppressants is still unknown. These data must be obtained from field tests. To circumvent this uncertainty, life expectancies of $1 / 2,1,2,3$ and 4 yrs were assumed. Also, three application rates- $1,3 / 4$, and $1 / 2$ of the manuf acturers' recommended concentrations--were 
used in this study. Finally, the life expectancy of an active tailings pile and the interim dust control period for an inactive pile were both assumed as 10 yrs.

Based on the above assumptions, the annual cost for fugitive dust control for the hypothetical uranium mill tailings can be calculated by the following equations.

For an active tailings pile,

$$
\begin{aligned}
C_{A}= & {\left[\left(C_{P}+C_{W}+C_{S}+C_{M} \times R\right) \times 3 / 4\right.} \\
& \left.+\left(C_{P}+C_{W}+C_{S} \times F+C_{M} \times R\right) \times Y / y+C_{M M} \cdot Y\right] / Y
\end{aligned}
$$

and for an inactive tailings pile,

$$
C_{I}=\left[C_{P}+C_{W}+\left(C_{S}+C_{M} \times R\right) \times Y / Y+C_{M M} \times Y\right] / Y
$$

where

$$
\begin{aligned}
& C_{A}=\text { annual cost of fugitive dust control for an active mill tail- } \\
& \text { ings pile, \$/100 acres } \\
& C_{I}=\text { annual cost of fugitive dust control for an inactive mill tail- } \\
& \text { ings pile, } \$ / 100 \text { acres } \\
& C_{M}=\text { cost of suppressant based on manuf acturers' recommended app } 1 \text { i- } \\
& \text { cation rate, } \$ / 100 \text { acres } \\
& C_{M M}=\text { cost of monitoring and maintenance, } \$ / 100 \text { acres } / y r \\
& C_{P}=\text { cost of site preparation, } \$ / 100 \text { acres } \\
& C_{S}=\text { cost of spraying, } \$ / 100 \text { acres } \\
& C_{W}=\text { cost of watering during site preparation, } \$ / 100 \text { acres } \\
& F=\text { adjustment factor to take account of the time required for } \\
& \text { setting up equipment for spraying each of the } 1 / 4 \text { of the } \\
& \text { tailings ( } 1.5 \text { was used here) } \\
& R=\text { ratio of concentration of applied suppressant to the manufac- } \\
& \text { turers' recommended value }(1,0.75 \text {, and } 0.5 \text { were used here) } \\
& Y=\text { life expectancy of an active tailings pile, or interim control } \\
& \text { period of an jnactive tailings pile (10 yrs is used here) } \\
& y=\text { effective life of a dust suppressant, yrs. }
\end{aligned}
$$


The $3 / 4$ in the first term of equation 2 defines the cost of treating the area of the tailings not covered by spigoting when initiating the dust control program (assumed here to be three-quarters). The second term is the cost of treating the new surface produced by advancing the spigot points around the periohery of the pile.

Results of a series of calculations for Coherex ${ }^{(B)}$, a typical dust suppressant used in many industries, are summarized in Figure 4 . The annual cost of fugitive dust contro $1, \$ / y r / 100$ acres is plotted against the effective 1 ife of the suppressant for different application rates. Also shown in the figure is the range of fugitive dust control cost using dust suppressants. Figure 4 shows that for a constant application concentration (e.g., the recommended suppressant concentration of Coherex), the cost of control decreases as the effective life of the suppressant increases. For the same effective life of the suppressant the cost of fugitive dust control decreases as the concentration of the applied suppressant decreases.

In the cost analysis it was found that material cost is the major contributor to the overall cost structure. Therefore, as the length of the effective life of the suppressant increases, and/or as the application rate decreases, the annual cost of fugitive dust control decreases rapidly. When a suppressant with a very high material cost, such as Sp-400 ${ }^{(1)}$, is used, the cost curve becomes very steep, meaning that the effective life of the suppressant is a very sensitive factor to the overall cost. On the other hand, when an inexpensive suppressant is used, the curve becomes very flat. Thus the effective life of the suppressant does not affect the overail cost significantly, as in the case of the Hydrodyne $C^{\circledR}$. In the latter case the cost of site preparation and monitoring-maintenance are comparable or even higher than the material cost and spraying. The ranges of fugitive dust control using suppressants with the highest and lowest costs, as listed in Table 3 , are in ratios of 31 to 1 and 17 to 1 for suppressants with effective lives of one and four years, respective $1 y$.

The costs of fugitive dust control for a hypothetical inactive tailings pile of 100 acres using soil cover, chemical dust suppressants, watering, geotextile and windscreen techniques are listed in Table 4 . These costs are based on a 10-yr average. It was assumed that $6 \mathrm{in}$. of top soil was needed to produce an effective dust controling barrier. Coherex was chosen as a representative chemical dust suppressant. In the cost calculations the effective "lives" of the suppresents were assumed as one, two, three and four years. In the watering calculation, $\$ 5 /$ day/acre (with spraying only one-half the time) was assumed. Three kinds of geotextiles were considered. The life expectancies of these materials were estimated as five years. Note that the dust control efficiencies of these materials range from $31 \%$ to $60 \%$ reduction $10 \%$ means no contro 1). Because no reliable data for the life expectancy and dust control efficiency are available for chemicals, geotextiles and other dust control techniques, it is difficult to make any direct cost comparison based on $\$ /$ area $\mathrm{yr} / \%$ of dust controlled. Therefore, the cost information shown in Table 4 gives the cost ranges of some of the candidate dust control techniques. Detailed cost information will be obtained when the field tests are completed. 


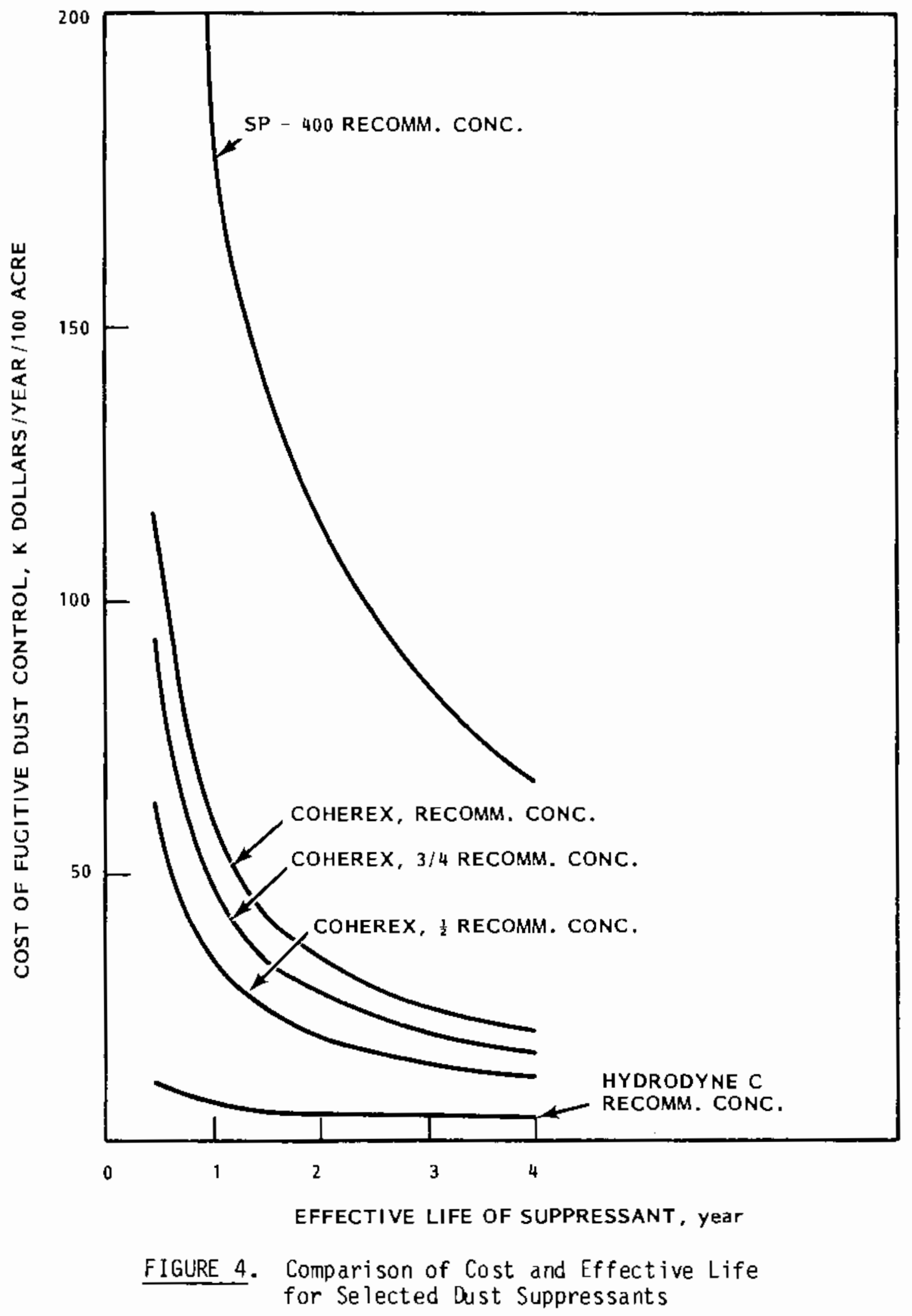


TABLE 4. Comparison of Costs For Selected Stabilization Techniques

Method

\begin{tabular}{lc}
\multicolumn{1}{c}{ Method } & $\$ / 100$ Acre/yr \\
\cline { 1 - 1 } 6-in. Soil Cover & 36,110 \\
Chemical (Coherex) & 54,700 \\
1 yr life expectancy & 28,650 \\
2 yrs life expectancy & 20,143 \\
3 yrs life expectancy & 94,230 \\
Watering (half-day) & \\
Geotextile(a) & 396,800 \\
Enkamat & 101,600 \\
Curlex Blanket & 87,100 \\
Polypropylene & 30,000 \\
Windscreen(b) & \\
(a) Emission Control--\% Reduction (30\% \\
to 60\%); life expectancy- 5 yrs. \\
(b) Life expectancy - 10 yrs.
\end{tabular}




\section{REFERENCES}

Arge11, G. 0., ed. 1978. Tailing Disposal Today. Miller Freeman Publications, Inc., San Francisco.

Armbrust, D. V., and J. D. Dickerson. 1971. Temporary Wind Erosion Control: Cost and Effectiveness of 34 Commercial Materials." J. of Soil and Water Conservation : 154-147.

Armour Industrial Chemical Co. November 1968. "Bituminous and Resinous Materials for Dust Control." Conducted for U.S. Army Engineers Waterways Experiment Station, Vicksburg, Mississippi.

Astrup, M. H. 1951. "Ground Cover Plants and Planting." HRB Roadside Dev. $11: 34-38$.

Bagnold, R. A. 1954. The Physics of Blown Sand and Desert Dunes. London: Methuen and Co., Ltd., London.

Belly, P. 1964. "Sand Movement by Wind, "Defense Documentation Center for Scientific and Technical Infomation.

Belser, B. 1982. "Bagnold of the Dunes." Science :30-35.

Bruns, L. E., K. T. Key and B. A. Higley. 1977. Hanford Cont aminated Sediment Stabilization Studies. ARH-CO-640, At lantic Richfield Inc, Richland, Washington.

Burri11, S. L., and G. W. Bossard. June 1971. "Tailings Dam Practice at ASARCO's Mission Plant." Paper presented at the AIME Environmental Quality Conf erence, Washington, D.C., June.

Canessa, W. 1977. "Chemical Retardants Control Fugitive Dust Problems." Pollution Engineering 9(7):24-26.

Capp, J. P., and D. W. Gilmore. 1973. "Soil Making Potential or Power Plant Fly Ash in Mined Land Reclamation." National Coal Association, Bituminous Coal Research, Inc., Monroeville, Pennsylvania. pp. 26-41.

Chepil, W. S. 1951. "Properties of Soil, which Influence Wind Erosion: V. Mechanical Stability of Structure." Soij Science 72:465-478.

Cross, F. L., Jr. 1980. "Control of Fugitive Dust from Buik Loading Facilities." Pollution Engineering 12(3):52-53.

Day, A. D., and K. L. Ludeke. 1978. "Disturbed Land Reclanation in an Arid Environment." In Tailing Disposal Today, pp. 437-460. 
Dean, K. C., and R. Havens. April 1971. "Stabilizing Mineral Wastes." Engr. Mining Journal :99-103.

Dean, K. C., and R. Havens. 1973. "Comparative Costs and Methods for Stabilization of Tailings." In Tailings Disposal Today, Proceedings of the International Tailing Symposium, C. L. Aplin and G. O. Rgall, Jr., eds., pp. 450-474. Miller Freeman Publications, San Francisco.

Dean, K. C., R. Havens and M. W. Glantz. May 1974. "Methods and Costs for Stabilizing Fine-Sized Mineral Wastes." Bureau of Mines RI7896.

Dean, K. C., R. Havens and K. T. Harper. May 1969. "Chemical and Vegetative Stabilization of a Nevada Copper Porphyry Mill Tailing." Bureau of Mines RI7261.

Denton, G. H., R. E. Hasse 1 and B. E. Scott. May 1972. "Minimizing InTransient Windage Losses of 0lga Low Volatile Coal." Paper presented at the 1972 Coal Show, American Mining Congress, Cleveland, Ohio. (Preprint by Dowel1 Division of the Dow Chemical Company).

Dretmel, D. C., B. E. Daniel and D. Carnes. 1982. "Relative Effectiveness of Chemical Additives and Wind Screens for Fugitive Dust Control." Environmenta] Progress 1(1): 16-20.

Gillette, D. A. 1973. "On the Production of Soil Wind Erosion Aerosols Having the Potential for Long-Range Transport," Special Issue of Journal de Recherches Atmospheriques on the Nice Symposium on the Chemistry of Sea-Air Particulate Exchange Processes, Nice, France.

Havens, R., and K. C. Dean. 1969. "Chemical Stabilization of the Uranium Tailings at Tuba City, Arizona." Bureau of Mines Report of

Investigations 7288 .

Jacko, R. B., and G. M. Palmer. 1980. "A Wind Tunnel Study of Fugitive Dust from Taconite Storage Piles." Presented at the Fourth Symposium on Fugitive Emissons, Measurements and Control, May 28-30, New Orleans, Louisiana.

Jones, J. N., Jr., H. H. Armiger and O. L. Bennett. 1975. "A Two-Step System for Revegetation of Surf ace Mine Spoils." J. Environ. Qual. 4(2):233-235.

Kalika, P. W., and P. Catizone. 1980. "Fugitive Emissions Concerns for Coal Storage and Handiing at Utility Operating Stations." Presented at the Fourth Symosium on Fugitive Emissions Measurement and Contro 1, May 28-30, New Or leans, Louisiana. PB81-174393, TRC Environmental Consultants, Inc., Wethersfield, Connecticut.

Kennedy, R. H. 1978. "Long Term Stabilization of Uranium Mill Tailings at Inactive Site." In Tailing Disposal Today, G. 0. Argell, Vol. 2 ed. Miller Freeman Publications, Inc., San Francisco. 
Kinsey, J. S., R. L. Kerch and J. M. Zoller. 1980. "A Review of Traditional and Non-Traditional Techniques for the Control of Fugitive Particulate Emissions." Paper presented at the 73rd Annual Meeting of the Air Pollution Control Association, Montreal, Quebec.

Knudsen, J. F., K. B. Hall and J. K. Horner. 1971. "Vegetative Stabilization of Tailings Ponds at Kennecott Copper Corp." Paper presented at the AIME Environmental Quality Conference, Washington, D.C.

Kozan, G. R., and J. D. Stouffer. April 1980. "Investigation of a Proprietary Chemical Agent for Soil Stabilization." Misc. Paper 5-70-11, U.S. Army Engineers Waterways Experiment Station, Vicksburg, Michigan.

Leroy, J. C. 1973. "How to Establish and Maintain Growth on Tailings in Canada--Cold winters and Short Growing Seasons." In Tailing disposal Today, Proceedings of the International Tajling Symposium, C. L. Aplin and G. 0. Argall, Jr., eds., pp. 411-449. Miller-Freeman Public ations, San Francisco.

Ludeke, K. L. 1973. Vegetative Stabilization of Copper Mine Tailings Disposal Berms of Pima Mining Co." In Tailing Disposal Today, Proceedings of the International Tailing Symposium, C. L. Aplin and G. D. Argall, Jr., eds., pp. 377-410. Miller-Freeman Publications, San Francisco.

Lyles, L., D. V. Armbrust, J. D. Dickerson, and N. P. Woodruff. 1969. "SprayOn Adhesives for Temporary Wind Erosion Control." J. Soil and Water Conservation : 190-193.

Mart in, D. J., E. Brookman, L. Hirsch, and D. Oremel. 1980. Control Methods for Fugitive Area Sources. Presented at the Fourth Symposium on Fugitive Emisions: Measrement and Controls, May 28-30.

NRC. 1980. "Final Generic Environmental Impact Statement on Uranium Milling." Office of Nuclear Material Safety and Saf eguards, NUREG-0706, Washington, D.C.

Parks, C. F., and R. B. Rosene. 1971. "An Evaluation of Stabilization of Active Tailings Ponds with Water-Swellable Polymers." Paper presented at the AIME Environmental Quality Conference, Washington, D.C.

PEDCO-Environmental Specialists, Inc. 1973. "Investigation of Fugitive DustSources, Emissions, and Control." Prepared for USEPA PB-266-693.

Pederson, J. R., and J. G. Schwind. 1973. "Amelioration of Coal Mine Spoils with Digested Sewage Sludge." In Proceedings of the Research and Applied Technology Symosium on Mineral Land Reclamation, National Coal Association, Bituminous Coal Research, Inc., Monroeville, Pennsylvania.

Schwendman, L. C. et al. 1980. A Field and Modeling Study of Windblown Particles from a Uranium Mill Tailings Piles. NUREG/CR-1407 (PNL-3345), Pacific Northwest Laboratory, Richland, Washington. 
Skelly and Loy Inc. 1973. "Processes, Procedures and Methods of Control Pollution from Mining Activities." EPA 430/9-73-011, U.S. Environmenta]

Protection Agency, Washington, D.C.

Suitan, H. A. 1976. "Chemical Stabilization for Control of Dust and Traffic Erosion." Transportation Research Board, Trans. Res. Rec. 593:34-40.

Sultan, H. A. 1974. Soil Erosion and Dust Control on Arizona Highways, Part II, Laboratory Testing Program. AOOT-RS-10-141-11, Arizona Transportation and Traffic Institute, College of Engineering, University of Arizona, Tuc son, Arizona.

Sutton, P. 1973. "Establishment of Vegetation on Toxic Mine Spoils." In Proceedings of Research and Applied Technology Symposium on Mined Land Reclamation, National Coal Association, Bituminous Coal Research, Inc., Monroeville, Pennsylvania, pp. 153-158.

USFS. 1972. Palzo Reclamation Project: Environmental Impact Study, U.S. Forest Service, Region 9, Milwakee, Wisconsin.

USNRC. 1980. Final Generic Environmental Impact Statement on Uranium Milling. U.S. Nuc lear Regulatory Commission, Silverspring, Maryland.

Veel, A. E., and C. H. Carr. 1980. "Control of Fugitive Emissions from Coal Storage Piles." Paper presented at the Fouth Symposium on Fugitive Emissions Measurement and Contro1, May 28-30, New Or leans, Louisiana.

Voorhees, L. D., M. J. Sale, J. W. Webb, and P. J. Mulholland. 1982. Guidance for Disposal of Uranium Mill Tailings: Long-Tem Stabilization of Cover Materials. Oak Ridge National Laboratory, prepared for Nuc lear Regulatory Commission, Washington, D.C.

Williams, R. E, 1975. Waste Production and Disposal in Mining Milling and Metallurgical Industries. Miller Freeman Publications, Inc.

Yardley, D. H., W. D. Lacabanne and C. R. Ne lson. November 1980. Airborne Dust from Taconite Tailings. 20265055, University of Minnesota, Minneapolis, Minnesota.

Zingg, A. W., and W. S. Chepi1. 1950. "Aerodynomics of Wind Erosion." Agricultural Engineering :279-282. 

APPENDIX A

ADDITIONAL MANUFACTURERS CONTACTED

Be low is a list of manufacturers and suppliers reported in the literature as having products used as dust suppressants. However, for one reason or another they no longer supply these materials, or chose not to participate in the study. This list is presented only to show the extent to which the industry was covered.

ALCO Chemicals

Philade lphia, Pennsylvania

Allied Chemicals

Morristown, New Jersey

American Hoescht Corp. Somerville, New Jersey

At las Minerals and Chemicals

Mert ztown, Pennsylvania

Ashl and Chemical Co.

Columbus, Ohio

Armac Chemical Co.

McCook, Illionis

Betz Laboratories, Inc.

Trevose, Pennsylvania

Borg Warner

Marbon Chemical Div.

Washington, West Virginia

Burke Rubger Co.

Div. of Burke Industries

San Jose, California
Eastman Chemical Products, Inc. Kingsport, Tennessee

EXXON Chemicals

San Mateo, California

General Latex and Chemical Co. Cambridge, Massachusetts

Hooker Chemical Co.

Pottstown, Pennsyivania

Kaiser Chemicals

Columbus, Ohio

Mateson Chemical Corp.

Phi lade iphia, Pennsylvania

Rohm and Haus Co.

Portland, Orgegon

Shell 0il Co.

Anaheim, California

Tenneco Cherricals

Chic ago, Illionis

Thiokol, Chemical Div.

Trenton, New Jersey 
Douglas $0 i 1$ Co.

Santa Maria, California

Velsicol Chemical Corp.

E. I. duPont deNemours and Co., Inc.

Chic ago, Illionis

wilmington, Delaware 
NUREG/CR -2856

PNL-4360

RU-

DISTR IBUT ION

No. of

Copies

OFFSITE

485 U.S. Nuclear Regulatory Comission Division of Technical information and Document Control

7920 Norfolk Avenue

Bethesda, MD 20014

2 DOE Technical Information Center

J. J. Davis

D. F. Harmon

NRC Office of Nuclear Regulatory Research

Washington, DC 20555

P. J. Garcia

NRC Office of Nuc lear Material Safety and Safeguard

Washington, DC 20555

Mark Matthews

Uranium Mill Tailings Remedial

Action Project

DDE Albuquerque Operations office

P.0. Box 5400

A7buquerque, NM 87115
No. of

Copies

QNSITE

50 Pac if ic Northwest Laboratory

T. J. Bander

L. L. Cadwell

M. R. Elmore (10)

G. W. Gee

J. N. Hartiey (20)

C. T. Li (5)

C. G. Lindsay

J. Mishima

G. B. Parker

L. C. Schwendiman

W. H. Walters

N. A. Wogman

Publishing Coordination (PY)(2)

Technical Information (5) 



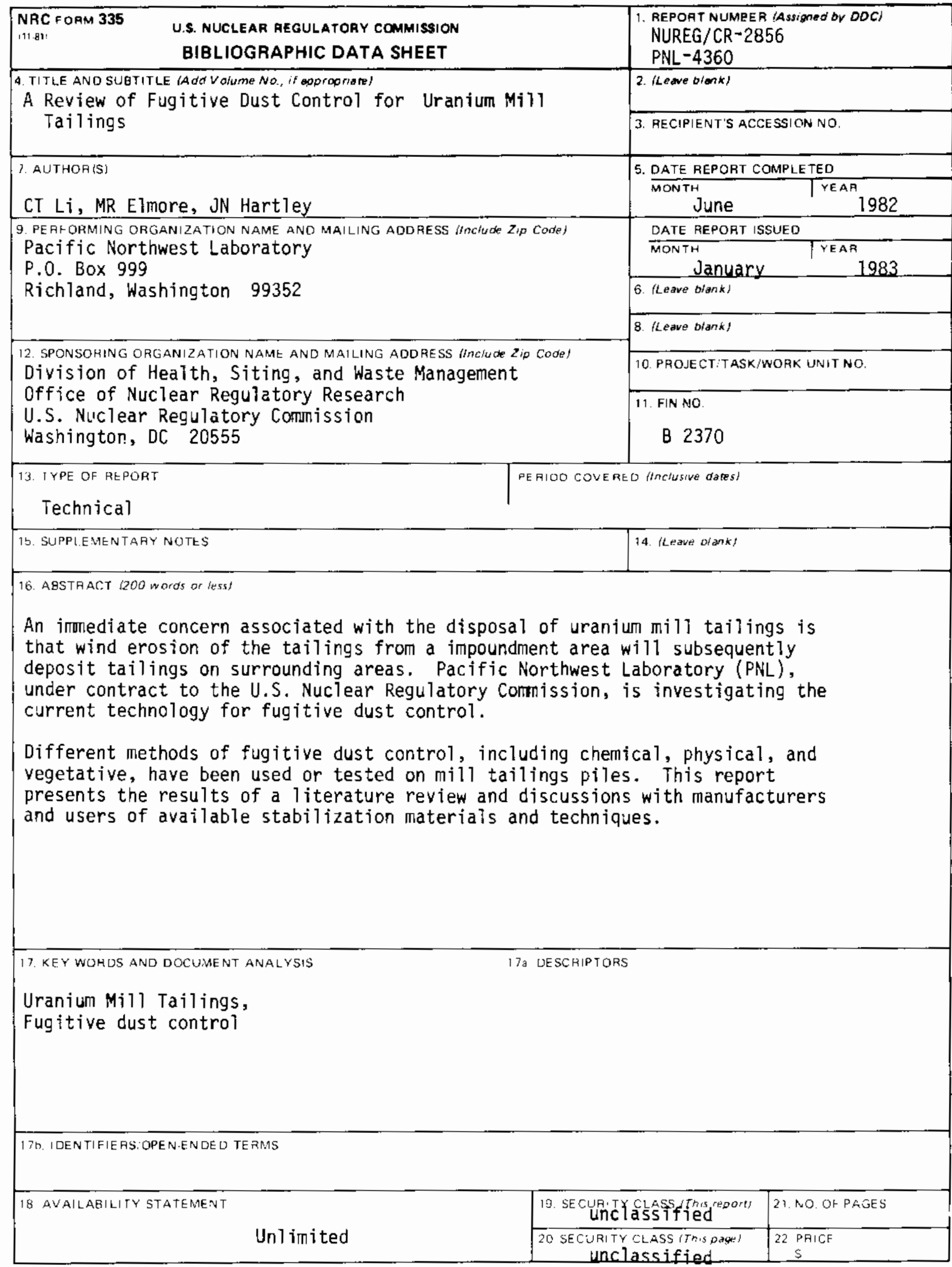


